Article

\title{
Efficient Mercury Removal at Ultralow Metal Concentrations by Cysteine Functionalized Carbon-Coated Magnetite
}

\author{
Assadawoot Srikhaow ${ }^{1}$ (), Teera Butburee ${ }^{2}$, Weeraphat Pon-On ${ }^{3}$, Toemsak Srikhirin ${ }^{4}$, \\ Kanchana Uraisin ${ }^{5}$, Komkrit Suttiponpanit ${ }^{6}$, Suwilai Chaveanghong ${ }^{7}$ \\ and Siwaporn Meejoo Smith $7, *$ (1) \\ 1 Materials Science and Engineering Graduate Program, Faculty of Science, Mahidol University, Rama VI Rd., \\ Rajathevi, Bangkok 10400, Thailand; assadawoot.sri@gmail.com \\ 2 National Nanotechnology Center (NANOTEC), National Science and Technology Development Agency, \\ 111 Thailand Science Park Phaholyothin Rd., Klong Nueng, Klong Luang, Pathumthani 12120, Thailand; \\ teera.but@nanotec.or.th \\ 3 Department of Physics, Faculty of Science, Kasetsart University,50 Ngam Wong Wan Rd., Ladyaow, \\ Chatuchak, Bangkok 10900, Thailand; fsciwpp@ku.ac.th \\ 4 Department of Physics, Faculty of Science, Mahidol University, Rama VI Rd., Rajathevi, \\ Bangkok 10400, Thailand; toemsak.sri@mahidol.ac.th \\ 5 Department of Chemistry and Center of Excellence for Innovation in Chemistry, Faculty of Science, \\ Mahidol University, Rama VI Rd., Rajathevi, Bangkok 10400, Thailand; kanchana.ura@mahidol.ac.th \\ 6 Environmental Technology Research Department, Innovation Institute, PTT Public Company Limited, \\ 71/1 M.2 Phaholyothin Rd., Sanubtub, Wangnoi, Ayutthaya 13170, Thailand; komkrit.su@pttplc.com \\ 7 Center of Sustainable Energy and Green Materials and Department of Chemistry, 999 Phuttamonthon Sai 4 Rd, \\ Salaya, Nakhon Pathom 73170, Thailand; suwilai.materialscience@gmail.com \\ * Correspondence: siwaporn.smi@mahidol.edu; Tel.: +66-2-4419817 (ext. 1171); Fax: +66-2354-7151
}

Received: 6 October 2020; Accepted: 19 November 2020; Published: 21 November 2020

Featured Application: This study highlights the utility of L-cysteine, a thiol-containing amino acid, as a functionalizing reagent for enhancing the adsorption capacity of $\mathrm{Hg}$ (II) ions by carbon-coated magnetite sorbents.

\begin{abstract}
This work reports the preparation and utility of cysteine-functionalized carbon-coated $\mathrm{Fe}_{3} \mathrm{O}_{4}$ materials (Cys-C@ $@ \mathrm{Fe}_{3} \mathrm{O}_{4}$ ) as efficient sorbents for remediation of $\mathrm{Hg}(\mathrm{II})$-contaminated water. Efficient removal (90\%) of $\mathrm{Hg}$ (II) from $1000 \mathrm{ppb}$ aqueous solutions is possible, at very low Cys-C@ $@ \mathrm{Fe}_{3} \mathrm{O}_{4}$ sorbent loadings ( $0.01 \mathrm{~g}$ sorbent per liter of $\mathrm{Hg}$ (II) solution). At low metal concentrations (5-100 ppb $\mathrm{Hg}(\mathrm{II})$ ), where adsorption is typically slow, $\mathrm{Hg}$ (II) removal efficiencies of $94-99.4 \%$ were achievable, resulting in final $\mathrm{Hg}$ (II) levels of $<1.0 \mathrm{ppb}$. From adsorption isotherms, the $\mathrm{Hg}$ (II) adsorption capacity for Cys- $\mathrm{C}_{\mathrm{Fe}} \mathrm{O}_{4}$ is $94.33 \mathrm{mg} \mathrm{g}^{-1}$, around three times that of carbon-coated $\mathrm{Fe}_{3} \mathrm{O}_{4}$ material. The highest partition coefficient (PC) of $2312.5 \mathrm{mgg}^{-1} \mu \mathrm{M}^{-1}$ was achieved at the initial $\mathrm{Hg}$ (II) concentration of $100 \mathrm{ppb}$, while significantly high PC values of $300 \mathrm{mgg}^{-1} \mu \mathrm{M}^{-1}$ and above were also obtained in the ultralow concentration range ( $\leq 20 \mathrm{ppb})$. Cys- $\mathrm{C} @ \mathrm{Fe}_{3} \mathrm{O}_{4}$ exhibits excellent selectivity for $\mathrm{Hg}$ (II) when tested in the presence of $\mathrm{Pb}(\mathrm{II}), \mathrm{Ni}(\mathrm{II})$, and $\mathrm{Cu}(\mathrm{II})$ ions, is easily separable from aqueous media by application of an external magnet, and can be regenerated for three subsequent uses without compromising $\mathrm{Hg}$ (II) uptake. Derived from commercially available raw materials, it is highly possible to achieve large-scale production of the functional sorbent for practical applications.
\end{abstract}

Keywords: adsorption; magnetite; mercury; surface functionalization 


\section{Introduction}

Mercury contamination of ground and surface water, and bioaccumulation of this heavy metal in aquatic and marine animals, presents serious concerns to public health and food safety worldwide [1-5]. Damage to the central nervous system, liver, kidneys, and heart in humans can be attributed to mercury exposure, the extent of which depends on the mercury form, dosage, and age and underlying health of the individual [6]. Major sources of environmental mercury contamination arise from waste effluents, such as those from mining, the chloralkali process, and petroleum industries [7]. Due to its acute toxicity, the World Health Organization (WHO) and European Union (EU) define permissible limits of total mercury in drinking water as being not greater than $1.0 \mathrm{ppb}$ [8]. Based on literatures, though with its high toxicity, the number of papers reporting $\mathrm{Hg}$ (II) removal from water [9-23] have been found much less than those focused on other heavy metal pollutant such as ions of $\mathrm{Cu}, \mathrm{Pb}, \mathrm{Zn}, \mathrm{Cr}$, or $\mathrm{Cd}$. Scopus-sorbents comparative details of the performance of several sorbents for $\mathrm{Hg}$ (II) removal are given, however, they are limited $[12,13,24]$. Besides, reports of effective sorbents for the removal of $\mathrm{Hg}$ (II) in water at low initial concentrations ( $\leq 100 \mathrm{ppb}$ ) are scarce [10,12-16]. Adsorption of $\mathrm{Hg}$ (II) has been found to be less effective at ultralow initial concentrations ( $\leq 20 \mathrm{ppb})$ [10] and is hampered due to the very small difference in $\mathrm{Hg}$ (II) concentration in solution relative to that at the sorption sites, resulting in very slow adsorption rates $[25,26]$. Therefore, treatment of $\mathrm{Hg}$ (II) contaminated water at such ultralow concentrations is very challenging, especially with the need to ensure quality levels comply with the WHO and EU permissible limits for drinking water (1.0 ppb) [8,26]. Commercially available and laboratory-scale synthetic activated carbon materials have been extensively reported as sorbents for $\mathrm{Hg}$ (II) ions, however, with low adsorption capacities (less than $20 \mathrm{mg} / \mathrm{g}$ ) [24]. Recently, magnetic sorbents, i.e., zero-valent iron, magnetite $\left(\mathrm{Fe}_{3} \mathrm{O}_{4}\right)$, and maghemite $\left(\gamma-\mathrm{Fe}_{2} \mathrm{O}_{3}\right)$, easily recovered by application of an external magnetic field, have attracted great interest as effective sorbents for the removal of metal ions from water [17-22,27]. To enhance the stability of such sorbents, the magnetic core should be coated by a protective shell to avoid corrosion, as is possible at low $\mathrm{pH}$ or under other extreme conditions. Shell materials can be organic or inorganic, with stabilities dependent on the chemical nature of the material. For example, carbon shell coatings proved more stable than those of functionalized (chitosan, polyamidoamine, and mesoporous silica) materials at low/high $\mathrm{pH}$ and at high temperature/pressure [28-32]. Previously, Faulconer et al. [14] utilized a magnetic powdered activated carbon material at high sorbent dosage $(1.0 \mathrm{~g} / \mathrm{L})$ in the adsorption of $\mathrm{Hg}(\mathrm{II})$ from aqueous solutions containing $100 \mathrm{ppb}$ of the toxic metal. The $\mathrm{Hg}$ (II) removal efficiency was only $84 \%$ after $180 \mathrm{~min}$, additionally having no evidence of the sorbent recyclability.

Effective sorbents for water remediation based on carbon-coated $\mathrm{Fe}_{3} \mathrm{O}_{4}$ materials have been fabricated recently, through one-step solvothermal treatment of an aqueous Fe(III) solution or aqueous $\mathrm{Fe}(\mathrm{III})$ and $\mathrm{Fe}(\mathrm{II})$ mixture in the presence of urea and glucose $[29,33,34]$. The high adsorption capacity of metal ions on these materials was due to the presence of oxygen-containing functional groups on the carbon surface, which electrostatically interact with metal ions. Surface oxygen functionalities can be further modified chemically, resulting in greater adsorption site density and, more importantly, the potential for selective metal ion adsorption. Enhanced adsorption capacities for metal ions have been demonstrated for sorbents functionalized with $\mathrm{OH}, \mathrm{C}=\mathrm{O}, \mathrm{COOH}, \mathrm{NH}$, and $\mathrm{SH}$ groups, as in carboxyl-, ketoxime-, and 1-(2-thiazolylazo)-2-naphthol carbon-coated magnetite sorbents [35-37], as well as $-\mathrm{N}\left(\mathrm{CH}_{2} \mathrm{COOH}\right)_{2}$-containing polymer/ $\mathrm{Fe}_{3} \mathrm{O}_{4}$ composites [12] and mercapto-functionalized nano- $\mathrm{Fe}_{3} \mathrm{O}_{4}$ magnetic polymers [13].

This work describes the synthesis of a series of magnetic sorbents for removal of aqueous $\mathrm{Hg}$ (II) from water samples, over a wide concentration range (5-1000 ppb). Using a one-pot synthesis, carbon-coated $\mathrm{Fe}_{3} \mathrm{O}_{4}$ nanoparticles $\left(\mathrm{C} @ \mathrm{Fe}_{3} \mathrm{O}_{4}\right)$ were obtained, and these were subjected to surface modification using L-cysteine, an amino acid with three functional groups (- $\left.\mathrm{SH}_{2},-\mathrm{NH}_{2},-\mathrm{COOH}\right)$, to afford Cys-C@ $\mathrm{Fe}_{3} \mathrm{O}_{4}$ particles. The $\mathrm{Hg}$ (II) removal efficiency of all sorbents $\left(\mathrm{Fe}_{3} \mathrm{O}_{4}, \mathrm{C}_{0} \mathrm{Fe}_{3} \mathrm{O}_{4}\right.$, and $\mathrm{Cys}-\mathrm{C} @ \mathrm{Fe}_{3} \mathrm{O}_{4}$ ) was examined under various conditions as part of a comprehensive study of the 
adsorption kinetics and thermodynamics, in addition to probing the selectivity of $\mathrm{Hg}$ (II) adsorption in the coexistence of other contaminant metal ions.

\section{Materials and Methods}

\subsection{Chemicals}

Iron (III) chloride hexahydrate $\left(\mathrm{FeCl}_{3} \bullet 6 \mathrm{H}_{2} \mathrm{O}\right.$, Sigma Aldrich), urea (Ajax Finechem), ethylene glycol (Ajax Finechem), D-glucose (Ajax Finechem), L-cysteine (Sigma Aldrich), mercury (II) nitrate monohydrate $\left(\mathrm{Hg}\left(\mathrm{NO}_{3}\right)_{2} \bullet \mathrm{H}_{2} \mathrm{O}, \mathrm{QRëC}\right)$, thiourea (Ajax Finechem), sodium hydroxide ( $\mathrm{NaOH}$, Merck), and hydrochloric acid $(\mathrm{HCl}, 37 \% \mathrm{w} / \mathrm{v}, \mathrm{RCI}$ Labscan) were of analytical grade and used as received. Ultrapure water, purified using a Millipore Milli-Q system $(18 \mathrm{M} \Omega \mathrm{cm})$, was used throughout the experiments.

\subsection{Sample Preparation}

Carbon-coated (Carbon@ $\mathrm{Fe}_{3} \mathrm{O}_{4}$ ) nanoparticles were prepared using a solvothermal method reported by Zheng et al. [34]. Briefly, $\mathrm{FeCl}_{3} \bullet 6 \mathrm{H}_{2} \mathrm{O}(0.8 \mathrm{~g})$ was dissolved in $60 \mathrm{~mL}$ of ethylene glycol with stirring. After a clear solution was obtained, urea $(3.0 \mathrm{~g})$ and D-glucose $(0.36 \mathrm{~g})$ were added, and the mixture was stirred at room temperature for $30 \mathrm{~min}$. Subsequently, the solution was transferred to a Teflon-lined stainless-steel autoclave and solvothermally treated at $200{ }^{\circ} \mathrm{C}$ for $12 \mathrm{~h}$. Notably, previous works suggested that solvothermal temperatures of $160^{\circ} \mathrm{C}$ and above are required to obtain a single phase of magnetite phase $\left(\mathrm{Fe}_{3} \mathrm{O}_{4}\right)[29,38,39]$, and the boiling point of ethylene glycol is elevated due to the elevated pressure in the reactor and the colligative property of solutions [40-42]. After cooling down to room temperature and washing sequentially with ultrapure water and ethanol (each three times), the resulting carbon-coated $\mathrm{Fe}_{3} \mathrm{O}_{4}$ nanoparticles were magnetically separated from the solution using a neodymium magnet and dried at $60^{\circ} \mathrm{C}$ in a vacuum oven (SHEL LAB, Shelton Manufacturing, Inc., Cornelius, Oregon) for $12 \mathrm{~h}$. Uncoated $\mathrm{Fe}_{3} \mathrm{O}_{4}$ nanoparticles were synthesized from a solvothermal treatment of a $\mathrm{FeCl}_{3} / \mathrm{EG} /$ urea mixture (without addition of D-glucose). Cysteine-functionalized (Cys-C@ $\mathrm{Fe}_{3} \mathrm{O}_{4}$ ) particles were synthesized using a modified version of the protocol previously utilized in functionalization of iron oxide materials $[43,44]$. In a typical synthesis, an aqueous suspension of $\mathrm{C} @ \mathrm{Fe}_{3} \mathrm{O}_{4}$ nanoparticles $(1.0 \mathrm{~g}$ in $100 \mathrm{~mL}$ ) was ultrasonically treated for $30 \mathrm{~min}$, and then mixed with an aqueous solution of L-cysteine (250-1000 mg dissolved in $100 \mathrm{~mL}$ ). The $\mathrm{pH}$ of the suspension was adjusted to 5.8 using $0.1 \mathrm{M} \mathrm{HCl}$ or $0.1 \mathrm{M} \mathrm{NaOH}$, followed by stirring for $12 \mathrm{~h}$ under an $\mathrm{N}_{2}$ atmosphere at room temperature. The solid products were then separated using an external magnet, and cleaned by washing sequentially with water and ethanol (each three times). The particles were then vacuum dried at $60{ }^{\circ} \mathrm{C}$ for $12 \mathrm{~h}$ and were denoted as either $250 \mathrm{Cys}-\mathrm{C} @ \mathrm{Fe}_{3} \mathrm{O}_{4}, 500 \mathrm{Cys}-\mathrm{C} @ \mathrm{Fe}_{3} \mathrm{O}_{4}$, or 1000Cys-C@ $\mathrm{Fe}_{3} \mathrm{O}_{4}$, with the number reflecting the weight of L-cysteine added in the preparation. Scheme S1 (Supporting Information) summarizes sample preparation methods used in this study.

\subsection{Sample Characterization}

Powder X-ray diffraction (PXRD) measurements were conducted on a Bruker powder X-ray diffractometer (AXS model D8 advance) with $\mathrm{Cu} \mathrm{K \alpha}$ radiation, $\lambda=1.5418 \AA$, 3-s step time and $0.075^{\circ}$ step size. Fourier-transform infrared spectroscopy (FTIR) was measured over a range of $480-4000 \mathrm{~cm}^{-1}$ using a Perkin Elmer Fourier-transform infrared spectrometer (Spectrum GX FT-IR System). Thermogravimetric analyses (TGA) were performed on a TA Instruments thermogravimetric analyzer (SDT 2960 Simultaneous DSC-TGA), with samples heated from 25 to $800{ }^{\circ} \mathrm{C}$ (heating rate $20{ }^{\circ} \mathrm{C} / \mathrm{min}$ ) under an $\mathrm{N}_{2}$ atmosphere. Magnetic properties of samples were investigated using a Lakeshore vibrating sample magnetometer (VSM 7404) at room temperature (applied field -6000 to 6000 Oersted). Transmission electron microscopy (TEM) and high-resolution TEM were carried out on a JEOL transmission electron microscope (2100), operated at $200 \mathrm{keV}$. Zeta potential measurements were performed on a Malvern Instruments zeta potential analyzer (Zetasizer, Nano ZS), in water at 
$25^{\circ} \mathrm{C}$. Surface properties of sorbents were examined using $\mathrm{N}_{2}$ sorption on a Quantachrome Instrument (Nova 2000e). All samples were degassed at $200{ }^{\circ} \mathrm{C}$ for $10 \mathrm{~h}$ prior to measurements. Quantification of cysteine loading in Cys-C@ $\mathrm{Fe}_{3} \mathrm{O}_{4}$ particles was obtained through combustion sulfur analysis using a LECO (CHNS-628S) elemental analyzer.

\section{4. $\mathrm{Hg}(\mathrm{II})$ Adsorption Test}

The Hg(II) adsorption capacity of sorbents was examined using the following procedure. Typically, $1 \mathrm{mg}$ of the sorbent was dispersed into $100 \mathrm{~mL}$ of aqueous $1000 \mathrm{ppb} \mathrm{Hg}$ (II) (synthetic wastewater) in a polypropylene bottle. The suspension was shaken with a thermostatic shaker at $25^{\circ} \mathrm{C}$ and aliquots were removed at regular time intervals, with dispersed sorbent removed from the aliquot using a magnet. The liquid sample was then stabilized by addition of $5 \%(\mathrm{w} / \mathrm{v}) \mathrm{KMnO}_{4}$ solution, then mixing with $1 \%(\mathrm{v} / \mathrm{v}) \mathrm{HCl}$ solution. Prior to determination of the $\mathrm{Hg}(\mathrm{II})$ content, addition of sufficient amount of $12 \%(\mathrm{w} / \mathrm{v})$ hydroxylamine aqueous solution is required to remove the excess $\mathrm{KMnO}_{4}$ and to acquire clear solutions. Atomic absorption spectroscopy (Perkin Elmer, AAnalyst 200 equipped with FIAS 100 system) was utilized to determine the concentration of $\mathrm{Hg}$ (II) in the aliquot sample, through coupling with flow injection analysis system-hydride generation (FIAS-HG) (reductant $0.2 \%(\mathrm{w} / \mathrm{v}$ ) $\mathrm{NaBH} 4$ in $0.05 \%(\mathrm{w} / \mathrm{v}) \mathrm{NaOH}$, carrier solution $3 \%(\mathrm{v} / \mathrm{v}) \mathrm{HCl})$. The $\mathrm{Hg}(\mathrm{II})$ removal efficiency $(\%)[10,12]$ or breakthrough (BT, \%) [45] was calculated according to the formula

$$
\text { Removal efficiency }(\%)=\left(C_{0}-C_{t} / C_{0}\right) \times 100 \% \text {, }
$$

where $\mathrm{C}_{0}\left(\mathrm{mg} \mathrm{L}^{-1}\right)$ is the initial concentration of $\mathrm{Hg}(\mathrm{II})$ and $\mathrm{C}_{\mathrm{t}}\left(\mathrm{mg} \mathrm{L}^{-1}\right)$ is the concentration of $\mathrm{Hg}$ (II) ions after adsorption

The mercury uptake $\left(\mathrm{q}_{\mathrm{e}}, \mathrm{mg} \mathrm{g}^{-1}\right)$, and removal efficiency, was calculated according to the equation:

$$
\mathrm{q}_{\mathrm{e}}=\left(\left(\mathrm{C}_{0}-\mathrm{C}_{\mathrm{e}}\right) \times \mathrm{V}\right) / \mathrm{m},
$$

where $C_{0}$ is the initial mercury concentration in solution $\left(\mathrm{mg} \mathrm{L}^{-1}\right), \mathrm{C}_{\mathrm{e}}$ is the equilibrium concentration of mercury $\left(\mathrm{mg} \mathrm{L}^{-1}\right)$ after adsorption, $\mathrm{V}$ is the volume of the solution $(0.1 \mathrm{~L}$; in this study), and $\mathrm{m}$ is the weight of the sorbent used (g). The $500 \mathrm{Cys}-\mathrm{C} @ \mathrm{Fe}_{3} \mathrm{O}_{4}$ sample was employed to study $\mathrm{pH}$ dependence of $\mathrm{Hg}$ (II) removal, while $\mathrm{HCl}$ and $\mathrm{NaOH}$ were added for $\mathrm{pH}$ adjustment.

In addition, partition coefficients $\left(\mathrm{PC}, \mathrm{mg} \mathrm{g}^{-1} \mu \mathrm{M}^{-1}\right.$ ) were evaluated using the adsorption capacity or the mercury uptake $\left(q_{e}, \mathrm{mg} \mathrm{g}^{-1}\right)$ divided by the equilibrium concentration of mercury $(\mu \mathrm{M})$ after adsorption $[4,46]$.

$$
\mathrm{PC}=\left(\mathrm{q}_{\mathrm{e}} / \mathrm{C}_{\mathrm{e}}\right)
$$

\section{Results and Discussion}

\subsection{Sample Characterization}

TEM images of uncoated $\mathrm{Fe}_{3} \mathrm{O}_{4}$ and $\mathrm{C}_{0} \mathrm{Fe}_{3} \mathrm{O}_{4}$ (Figure 1a,b) show individual particles to be spherical, although these undergo aggregation. Uncoated $\mathrm{Fe}_{3} \mathrm{O}_{4}$ particles are larger (diameter 40-70 nm) than those of $\mathrm{C}_{\mathrm{Fe}} \mathrm{O}_{4}$. This finding is consistent with previous work reported by Zheng et al. [34] and Pham et al. [47]. With the addition of D-glucose in the reaction media, a thin carbon shell coating clusters of the magnetite particles are formed (cluster size 50-80 nm, Figure 1b). HRTEM (Figure 1c)

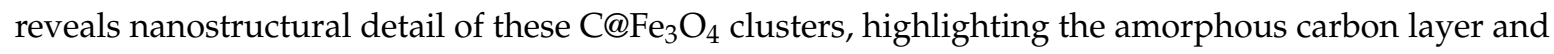
crystalline nature of the magnetite core, as indicated by the lattice spacing $(0.29 \mathrm{~nm})$ being consistent with the (002) plane of magnetite [48]. The smaller size of $\mathrm{C} \mathrm{Fe}_{3} \mathrm{O}_{4}$ particles relative to uncoated $\mathrm{Fe}_{3} \mathrm{O}_{4}$ suggests that glucose acts as both a precursor of carbon shell formation and crystallization inhibitor, resulting in slow $\mathrm{Fe}_{3} \mathrm{O}_{4}$ crystal growth. L-Cysteine loading appears to have no effect on the Cys-C@ $\mathrm{Fe}_{3} \mathrm{O}_{4}$ cluster size and the size of $\mathrm{Fe}_{3} \mathrm{O}_{4}$ particles (Figure 2), reflecting the stability of carbon-coated magnetite towards surface functionalization. 

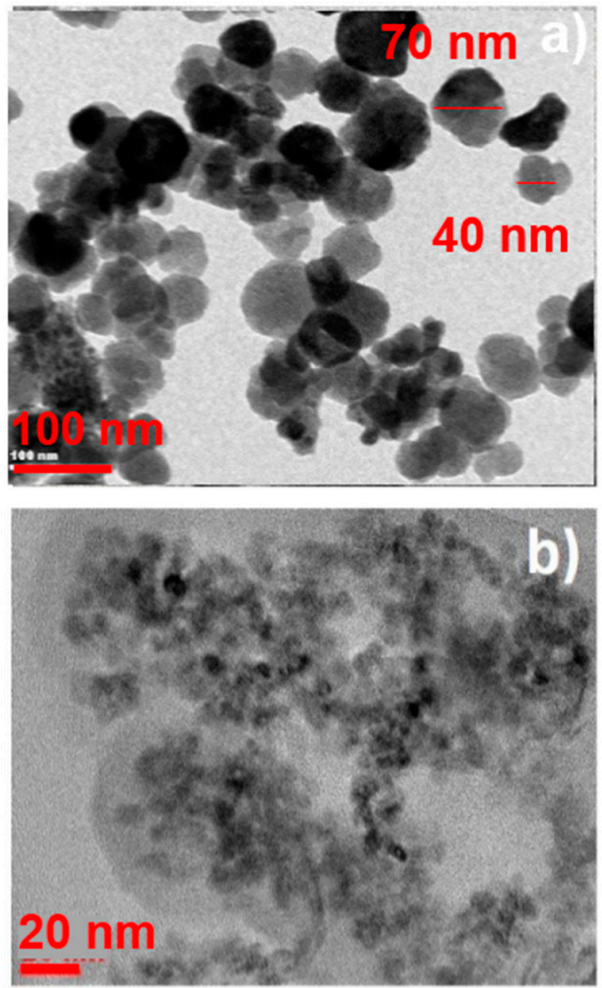

Figure 1. TEM images of (a) uncoated $\mathrm{Fe}_{3} \mathrm{O}_{4},(\mathbf{b}) \mathrm{C} @ \mathrm{Fe}_{3} \mathrm{O}_{4}$, and (c) $\mathrm{C} @ \mathrm{Fe}_{3} \mathrm{O}_{4}$.

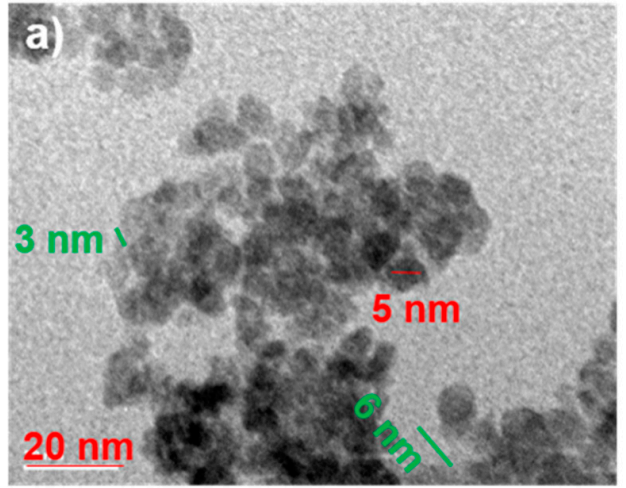

$\mathrm{C} @ \mathrm{Fe}_{3} \mathrm{O}_{4}$

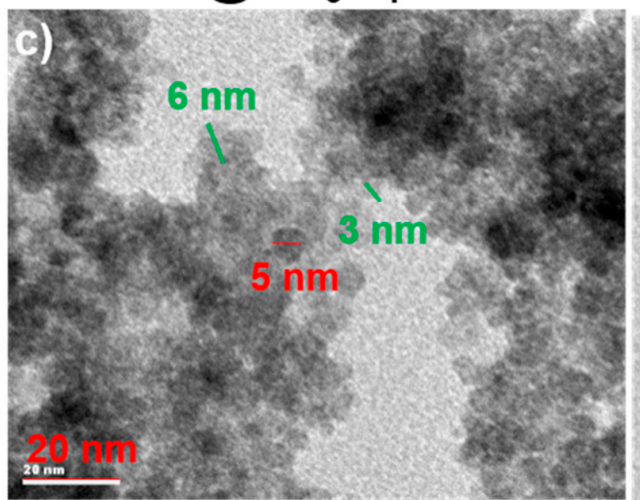

500Cys-C@ $\mathrm{Fe}_{3} \mathrm{O}_{4}$

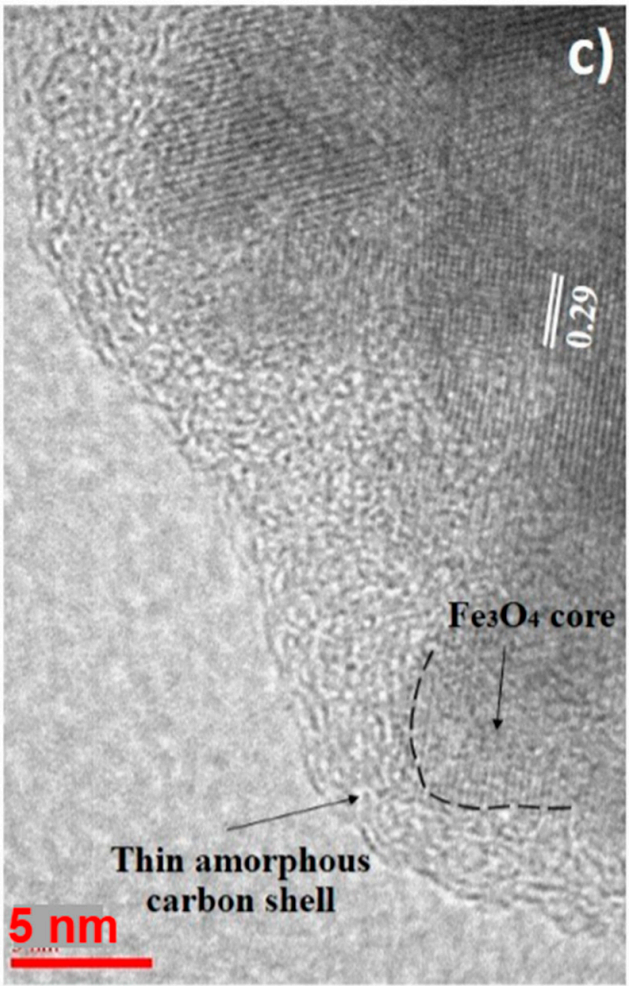

C)

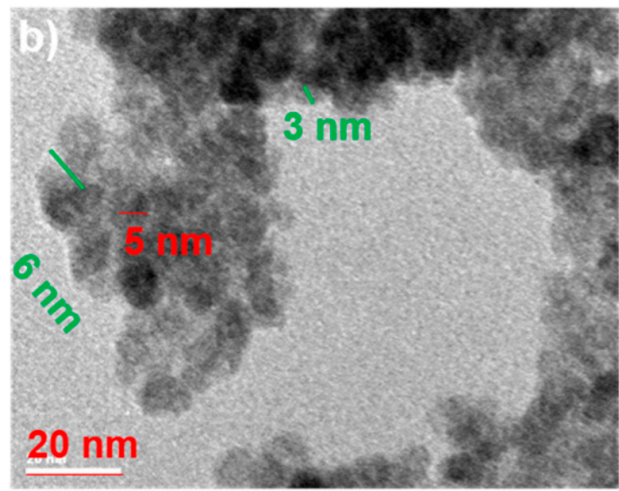

250Cys-C@ $\mathrm{Fe}_{3} \mathrm{O}_{4}$

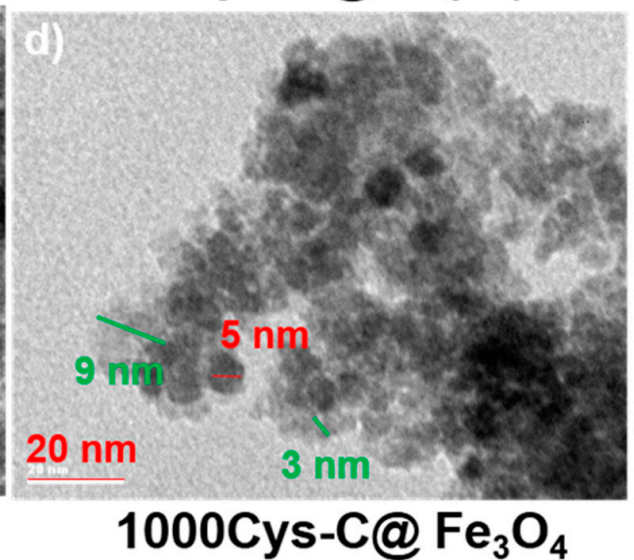

Figure 2. TEM images of (a) $\mathrm{C} @ \mathrm{Fe}_{3} \mathrm{O}_{4}$, (b) 250Cys-C@ $\mathrm{Fe}_{3} \mathrm{O}_{4}$, (c) $500 \mathrm{Cys}-\mathrm{C} @ \mathrm{Fe}_{3} \mathrm{O}_{4}$, and (d) $1000 \mathrm{Cys}-\mathrm{C} @ \mathrm{Fe}_{3} \mathrm{O}_{4}$. 


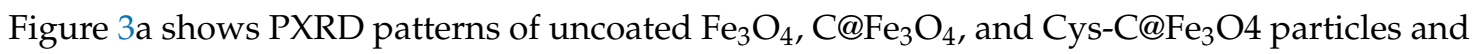
that of bulk L-cysteine for comparison. The characteristic peaks of magnetite $\left(\mathrm{Fe}_{3} \mathrm{O}_{4}\right.$, cubic phase, JCPDS file No. 75-1609) [36,48] appear in the diffraction patterns of all particles. However, the intensity of these magnetite peaks in $\mathrm{C} @ \mathrm{Fe}_{3} \mathrm{O}_{4}$ and Cys-C@ $\mathrm{Fe}_{3} \mathrm{O}_{4}$ samples is significantly lower than those in uncoated $\mathrm{Fe}_{3} \mathrm{O}_{4}$, possibly related to shielding by the surface layers [49]. XRD peaks corresponding to graphitic carbon were not observed in $\mathrm{C} @ \mathrm{Fe}_{3} \mathrm{O}_{4}$ and $\mathrm{Cys}-\mathrm{C} @ \mathrm{Fe}_{3} \mathrm{O}_{4}$, suggestive of amorphous carbon coatings in agreement with HRTEM observations. Additional XRD peaks corresponding to crystalline cysteine (2-theta: $18.3^{\circ}, 28.5^{\circ}, 31.4^{\circ}$, and $34.2^{\circ}$ ) being observed in $1000 \mathrm{Cys}-\mathrm{C} @ \mathrm{Fe}_{3} \mathrm{O}_{4}$ is probably the result from excess cysteine deposited on the carbon shell.

a)

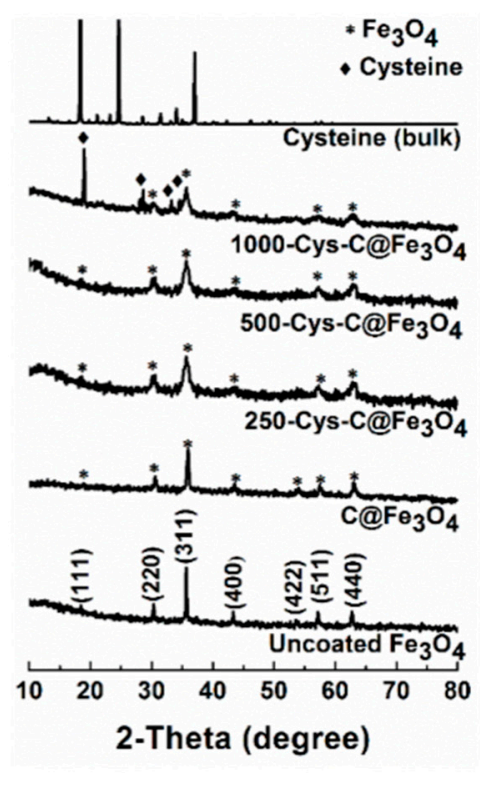

c)

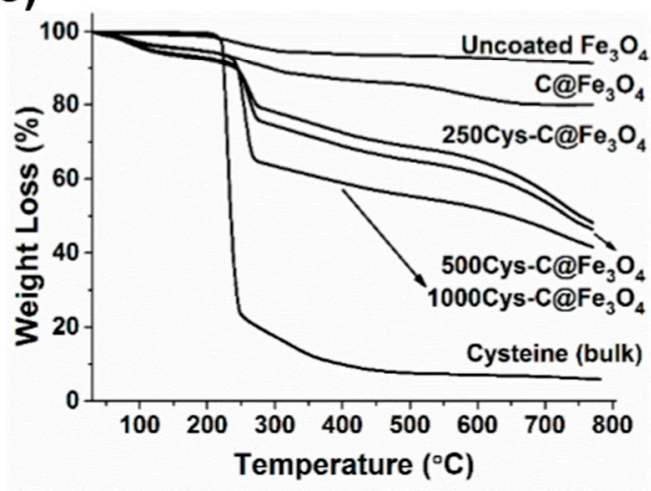

b)
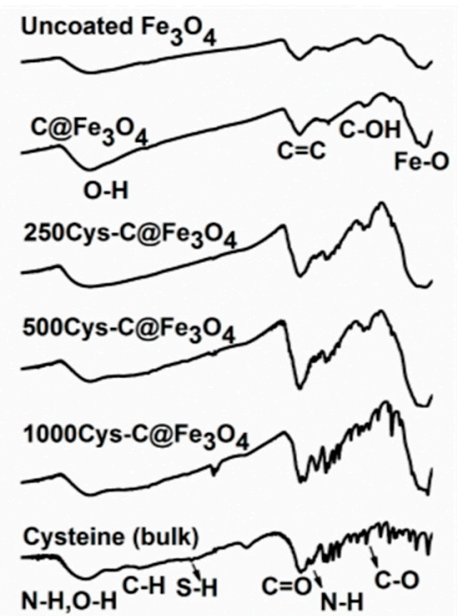

4000350030002500200015001000500 Wavenumber $\left(\mathrm{cm}^{-1}\right)$

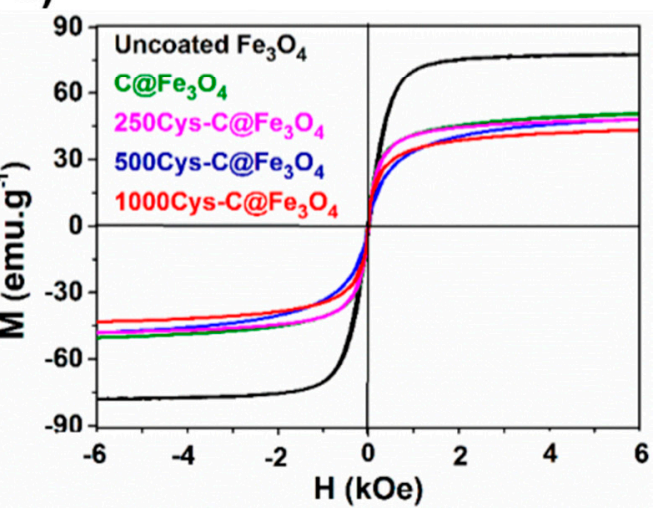

Figure 3. (a) Powder X-ray diffraction (PXRD) patterns, (b) FTIR spectra, (c) thermogravimetric (TG) curves, and (d) magnetic behavior of uncoated $\mathrm{Fe}_{3} \mathrm{O}_{4}, \mathrm{C} @ \mathrm{Fe}_{3} \mathrm{O}_{4}$, and Cys-C@ $\mathrm{Fe}_{3} \mathrm{O}_{4}$ materials. The $\mathrm{Y}$ axis in $(\mathbf{a}, \mathbf{b})$ are given in arbitrary unit.

The surface functionality of prepared sorbents was probed using FTIR. As shown in Figure 3b, the characteristic Fe-O stretching vibration appears at $570 \mathrm{~cm}^{-1}$ in all $\mathrm{Fe}_{3} \mathrm{O}_{4}$-based samples [36]. Peaks corresponding to $\mathrm{C}-\mathrm{OH}$ stretching and $\mathrm{O}-\mathrm{H}$ bending $\left(1069 \mathrm{~cm}^{-1}\right)$ occur in $\mathrm{C}_{0} \mathrm{Fe}_{3} \mathrm{O}_{4}$, with $\mathrm{C}=\mathrm{C}$ vibrations at $1620 \mathrm{~cm}^{-1}$ reflecting the successful carbonization of glucose to the coating layer [29]. Moreover, the relative intensity of the $\mathrm{O}-\mathrm{H}$ vibration $\left(3600-3100 \mathrm{~cm}^{-1}\right)$ is significantly higher in $\mathrm{C} @ \mathrm{Fe}_{3} \mathrm{O}_{4}$ samples relative to uncoated magnetite, indicating the greater abundance of these groups on the carbonized surface. The existence of these surface groups facilitates appendage of metal binding functionalities, in this case L-cysteine, to the particle periphery [34]. For Cys-C@ $\mathrm{Fe}_{3} \mathrm{O}_{4}$ samples, the presence of L-cysteine was confirmed by the $\mathrm{N}-\mathrm{H}$ vibration overlapping with the $\mathrm{O}-\mathrm{H}$ 
stretching frequency at $3600-3100 \mathrm{~cm}^{-1}$, and two bands at $1600 \mathrm{~cm}^{-1}$ and $1240 \mathrm{~cm}^{-1}$ attributed to $\mathrm{C}=\mathrm{O}$ and $\mathrm{C}-\mathrm{O}$ stretching of the amino acid, respectively [29]. Moreover, further peaks at $\sim 1500 \mathrm{~cm}^{-1}$ (N-H bending) and $2590 \mathrm{~cm}^{-1}$ (S-H stretching) are evident. These results confirm the grafting of L-cysteine to the particle surface, which most likely occurs via condensation between surface hydroxyl groups and the carboxylic acid moiety in L-cysteine [50]. CHNS analysis results were employed to confirm the presence of cysteine and to determine the cysteine content in Cys- $\mathrm{C} @ \mathrm{Fe}_{3} \mathrm{O}_{4}$ samples. These results suggest that cysteine content increases with cysteine loading, as found to be 0.0563 , 0.0963 , and $0.1828 \mathrm{mmol}$ per gram of solid samples of the $250 \mathrm{Cys}-\mathrm{C} @ \mathrm{Fe}_{3} \mathrm{O}_{4}, 500 \mathrm{Cys}-\mathrm{C} @ \mathrm{Fe}_{3} \mathrm{O}_{4}$, and 1000Cys-C@ $\mathrm{Fe}_{3} \mathrm{O}_{4}$, respectively.

Thermogravimetric (TG) analysis plots for all particle systems and that of bulk cysteine are illustrated in Figure 3c. The TGA profile of uncoated $\mathrm{Fe}_{3} \mathrm{O}_{4}$ shows around $2 \%$ weight loss between 100 and $400^{\circ} \mathrm{C}$, possibly due to loss of residual water and surface hydroxyl groups. On the other hand, three distinct weight loss steps are evident for $\mathrm{C} @ \mathrm{Fe}_{3} \mathrm{O}_{4}: 40-200,200$, and $>500{ }^{\circ} \mathrm{C}$, corresponding to the loss of surface hydroxyl groups and water molecules and the combustion of amorphous carbon shells [34]. In addition, the TGA curve of bulk cysteine highlights decomposition occurring between 200 and $450{ }^{\circ} \mathrm{C}$, while those of $\mathrm{Cys}-\mathrm{C} @ \mathrm{Fe}_{3} \mathrm{O}_{4}$ particles show three weight loss steps, below 230, 230-270, and $>500{ }^{\circ} \mathrm{C}$, which coincide with the loss of residual water and hydroxyl groups, cysteine decomposition, and the decomposition of the carbon shell, respectively $[33,50]$. With no change in weight after $680^{\circ} \mathrm{C}$, the total weight loss results are indicative of $81 \%$ wt./wt. $\mathrm{Fe}_{3} \mathrm{O}_{4}$ in $\mathrm{C}_{0} \mathrm{Fe}_{3} \mathrm{O}_{4}$ material. On the other hand, the steep slopes at around $800{ }^{\circ} \mathrm{C}$ in in TG plots of $250 \mathrm{Cys}-\mathrm{C} @ \mathrm{Fe}_{3} \mathrm{O}_{4}, 500 \mathrm{Cys}-\mathrm{C} @ \mathrm{Fe}_{3} \mathrm{O}_{4}$, and 1000Cys-C@ $\mathrm{Fe}_{3} \mathrm{O}_{4}$ systems indicate slower combustion (compared with $\mathrm{C} @ \mathrm{Fe}_{3} \mathrm{O}_{4}$ ), suggesting superior thermal stability arising from the presence of the cysteine layer. Furthermore, the residual mass of solid samples at $800{ }^{\circ} \mathrm{C}$ suggests the content of $\mathrm{Fe}_{3} \mathrm{O}_{4}$ in $250 \mathrm{Cys}-\mathrm{C} @ \mathrm{Fe}_{3} \mathrm{O}_{4}, 500 \mathrm{Cys}-\mathrm{C} @ \mathrm{Fe}_{3} \mathrm{O}_{4}$, and 1000Cys-C@ $\mathrm{Fe}_{3} \mathrm{O}_{4}$ to be not more than $50 \%, 49 \%$, and $40 \%$ wt./wt., respectively, and reflect the increase in cysteine content with initial loading level, as indicated from elemental sulfur analysis. Magnetic properties of all $\mathrm{Fe}_{3} \mathrm{O}_{4}$-based samples were examined using VSM at room temperature. Results depicted in Figure 3d show that the saturation magnetization of uncoated $\mathrm{Fe}_{3} \mathrm{O}_{4}, \mathrm{C}_{0} \mathrm{Fe}_{3} \mathrm{O}_{4}$, 250Cys-C@ $\mathrm{Fe}_{3} \mathrm{O}_{4}, 500 \mathrm{Cys}-\mathrm{C} @ \mathrm{Fe}_{3} \mathrm{O}_{4}$, and 1000Cys-C@ $\mathrm{Fe}_{3} \mathrm{O}_{4}$ samples were about 78, 51, 50, 49, and $45 \mathrm{emu.g}^{-1}$, respectively. Reductions in saturation magnetization after carbon coating and cysteine functionalization can be attributed to the decreasing fraction of magnetic material in these particles relative to diamagnetic coating materials (carbon and cysteine) [50,51].

Figure $\mathrm{S} 1$ shows $\mathrm{N}_{2}$ adsorption-desorption isotherms and pore size distributions of all samples, with porous structural data listed in Table 1. It can be concluded that isotherms of all materials are of type-IV with a type-H3 hysteresis loop, typical of mesoporous materials [51]. The greater specific area of $\mathrm{C} @ \mathrm{Fe}_{3} \mathrm{O}_{4}\left(90 \mathrm{~m}^{2} \cdot \mathrm{g}^{-1}\right)$ over that of uncoated $\mathrm{Fe}_{3} \mathrm{O}_{4}\left(55 \mathrm{~m}^{2} \cdot \mathrm{g}^{-1}\right)$ may be a consequence of the presence of pores in the carbon coating. Cysteine-modified C@ $\mathrm{Fe}_{3} \mathrm{O}_{4}$ samples show lower specific surface areas and total pore volumes than $\mathrm{C} \mathrm{Fe}_{3} \mathrm{O}_{4}$ due to grafting of the surface L-cysteine ligands, which results in blockage of surface channels and reduced porosity [52,53].

Table 1. Porous structural data for as-synthesized samples $\left(S_{B E T}\right.$, specific surface area by BET; $V_{\mathrm{t}}$, total pore volume; $D_{\mathrm{a}}$, average pore diameter).

\begin{tabular}{cccc}
\hline Sample & $S_{\text {BET }}\left(\mathbf{m}^{\mathbf{2}} \cdot \mathbf{g}^{-\mathbf{1}}\right)$ & $V_{\mathbf{t}}\left(\mathbf{c m}^{\mathbf{3}} \cdot \mathbf{g}^{-\mathbf{1}}\right)$ & $D_{\mathbf{a}}(\mathbf{n m})$ \\
\hline Uncoated $\mathrm{Fe}_{3} \mathrm{O}_{4}$ & 55 & 0.07 & 2.28 \\
C@ $\mathrm{Fe}_{3} \mathrm{O}_{4}$ & 90 & 0.11 & 2.24 \\
250Cys-C@ $@ \mathrm{Fe}_{3} \mathrm{O}_{4}$ & 30 & 0.04 & 2.44 \\
500 Cys-C@ $\mathrm{Fe}_{3} \mathrm{O}_{4}$ & 23 & 0.03 & 2.52 \\
1000 Cys-C@ $\mathrm{Fe}_{3} \mathrm{O}_{4}$ & 40 & 0.04 & 2.56 \\
\hline
\end{tabular}




\subsection{Adsorption Kinetics}

Figure 4 reports that at the initial $\mathrm{Hg}$ (II) concentration of $1000 \mathrm{ppb}, 100 \%$ breakthrough (BT) was not achievable for all of the studied sorbents after 60 min treatments. Low \%BT values (<30\%) for C@ $\mathrm{Fe}_{3} \mathrm{O}_{4}$ and uncoated $\mathrm{Fe}_{3} \mathrm{O}_{4}$ were obtained even after 60 min treatments. On the other hand, $90 \% \mathrm{BT}$ $\left(\mathrm{q}_{\mathrm{e}}=90.03 \mathrm{mg} \mathrm{g}^{-1}\right)$ for 500 Cys-C@ $\mathrm{Fe}_{3} \mathrm{O}_{4}$ were obtained after treatments for $45 \mathrm{~min}$ and above, while about $40 \% \mathrm{BT}\left(\mathrm{q}_{\mathrm{e}}=42.0 \mathrm{mg} \mathrm{g}^{-1}\right)$ was achieved after $5 \mathrm{~min}$. At BT time of $60 \mathrm{~min}$, the $\% \mathrm{BT}$ follows the order of 500Cys-C@ $\mathrm{Fe}_{3} \mathrm{O}_{4}>1000$ Cys-C@ $\mathrm{Fe}_{3} \mathrm{O}_{4}>250$ Cys-C@ $\mathrm{Fe}_{3} \mathrm{O}_{4}>>\mathrm{C}_{3} \mathrm{Fe}_{3} \mathrm{O}_{4}>$ uncoated $\mathrm{Fe}_{3} \mathrm{O}_{4}$, being consistent with the specific surface area, surface functional groups, and adsorption capacity relationship previously discussed. Notably, times to reach $10 \% \mathrm{BT}, 50 \% \mathrm{BT}$, and $90 \% \mathrm{BT}$ of the prepared magnetic sorbents, interpolated from Figure 4, are reported in Table S1. After 60 min of 500 Cys-C@ $\mathrm{Fe}_{3} \mathrm{O}_{4}$ treatments, 50\%BT and 90\%BT were achievable, respectively, at $\mathrm{pH}=2$ and $\mathrm{pH} \geq 6$ (Figure $\mathrm{S} 2$ and Table S2).

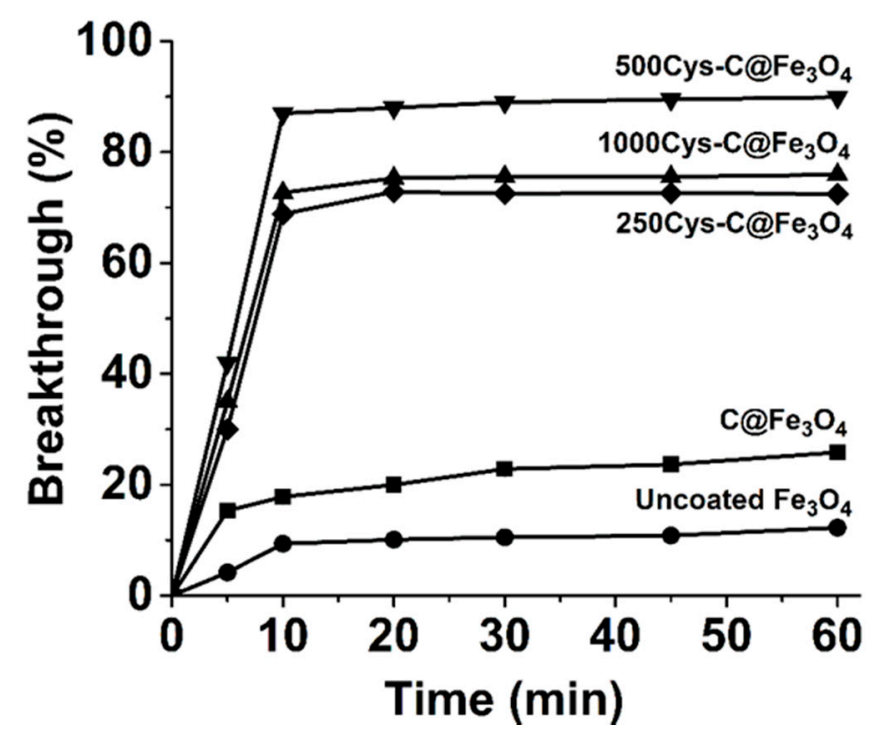

Figure 4. $\mathrm{Hg}$ (II) treatment time dependence of \% Breakthrough (BT) at initial $\mathrm{Hg}$ (II) concentration of $1000 \mathrm{ppb}$ and sorbent loading of $0.01 \mathrm{~g} \mathrm{~L}^{-1}$. High reproducibility of the measurements is indicated by small standard deviations from five identical batch experiments.

Kinetic results for $\mathrm{Hg}(\mathrm{II})$ adsorption, measured using $0.01 \mathrm{mg} \mathrm{L}^{-1}$ sorbent suspended in $1000 \mathrm{ppb}$ $\mathrm{Hg}$ (II) aqueous solution at $\mathrm{pH}$ 6, are illustrated in Figure 5a. For all samples, high $\mathrm{Hg}$ adsorption rate was observed during the first $10 \mathrm{~min}$ and reached an equilibrium after $20 \mathrm{~min}$. The greater adsorption efficiency of $\mathrm{C} @ \mathrm{Fe}_{3} \mathrm{O}_{4}$ relative to uncoated magnetite is likely due to the presence of surface hydroxyl groups, and its higher surface area. For Cys-C@ $\mathrm{Fe}_{3} \mathrm{O}_{4}$ samples, which exhibit lower surface area than $\mathrm{C} @ \mathrm{Fe}_{3} \mathrm{O}_{4}$, the relatively high adsorption capacity is related to the metal-chelating ability of the $-\mathrm{NH}_{2}$ and -SH functional groups in the appended L-cysteine. Notably, the highest $\mathrm{Hg}$ uptake was $90 \mathrm{mg} \cdot \mathrm{g}^{-1}$ by $500 \mathrm{Cys}-\mathrm{C} @ \mathrm{Fe}_{3} \mathrm{O}_{4}$. Further increases in cysteine content (1000Cys-C@ $\mathrm{Fe}_{3} \mathrm{O}_{4}$ ) resulted in lower $\mathrm{Hg}$ (II) removal efficiency, likely due to the deposition of bulk cysteine on the carbon shell (XRD result, Figure 3a) that could inhibit effective adsorption by internal pores. Mercury removal experiments were further conducted for longer periods $(60 \mathrm{~min})$ to ensure adsorption saturation. To study the adsorption mechanism, 500Cys- $\mathrm{C}_{\mathrm{Fe}} \mathrm{O}_{4}$, which exhibits the highest level of $\mathrm{Hg}$ (II) uptake, was selected as representative of $\mathrm{Cys}-\mathrm{C} @ \mathrm{Fe}_{3} \mathrm{O}_{4}$, along with uncoated $\mathrm{Fe}_{3} \mathrm{O}_{4}$ and $\mathrm{C} @ \mathrm{Fe}_{3} \mathrm{O}_{4}$ for comparison. Pseudo-second-order kinetic models (Figure $5 b$ ) were then applied to probe the mechanism $[33,54]$. The correlation coefficients for the pseudo-second-order kinetic model are very close to 1 , and the calculated equilibrium adsorption capacities $\left(q_{\mathrm{e}, \mathrm{cal}}\right)$ derived from this model are also much closer to the experimentally determined adsorption capacities $\left(q_{\mathrm{e}, \text { exp }}\right)$ than that derived using the pseudo first 
order kinetic model. These results also support the assumption that sorption should occur through chemical adsorption rather than mass transport [55].

a)
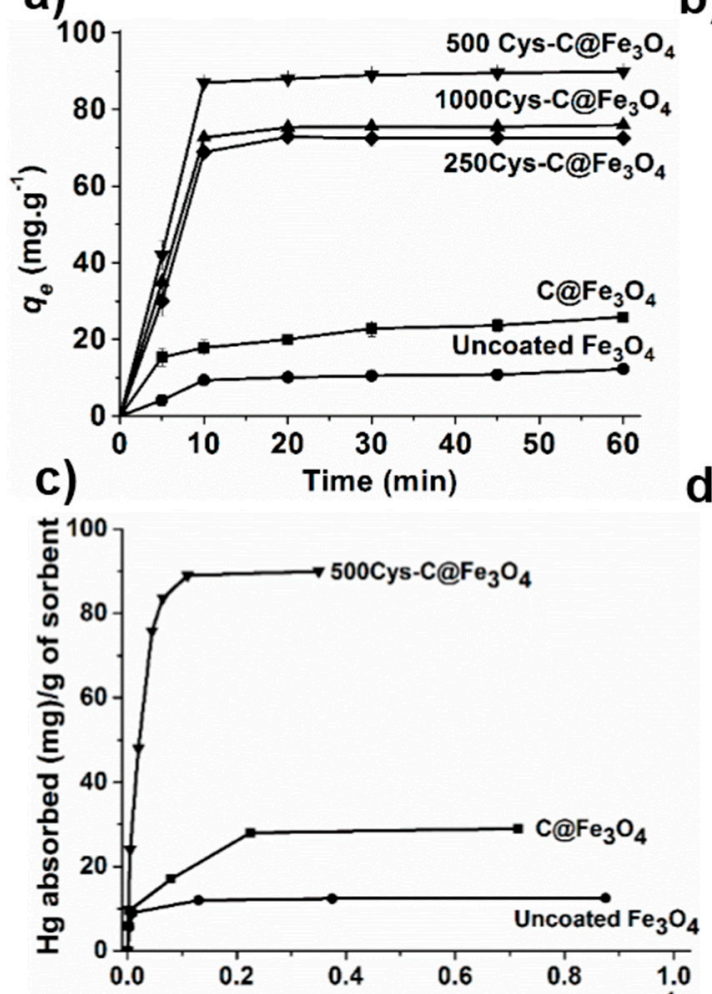

e)

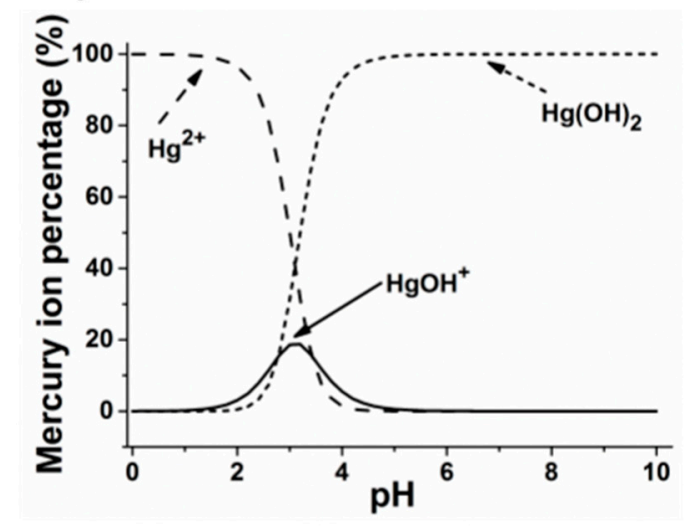

b)
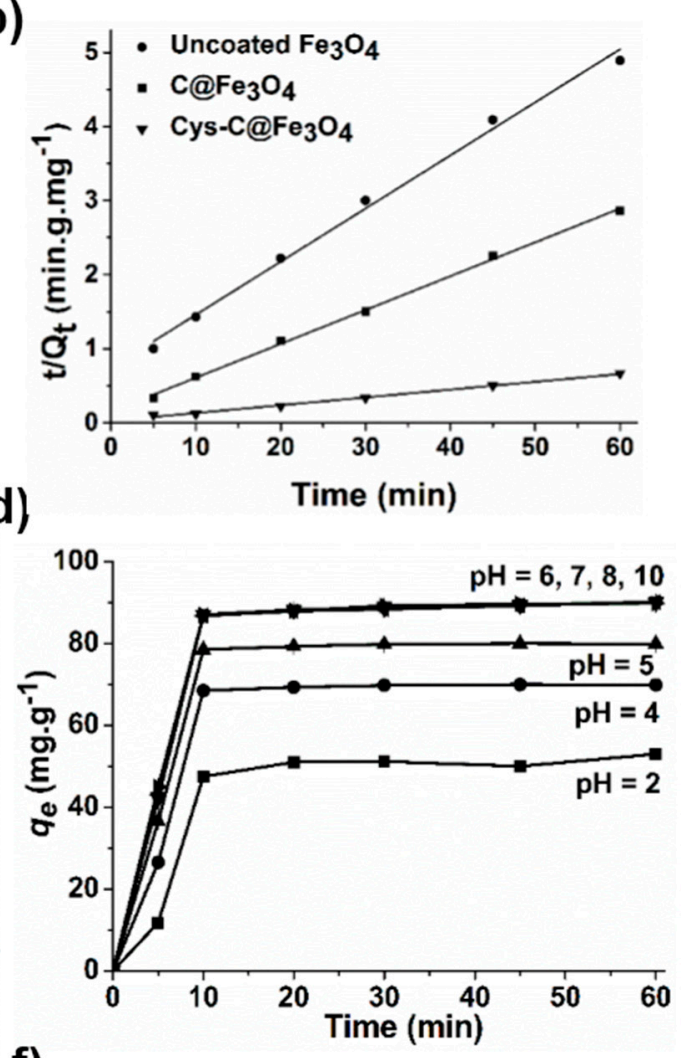

f)

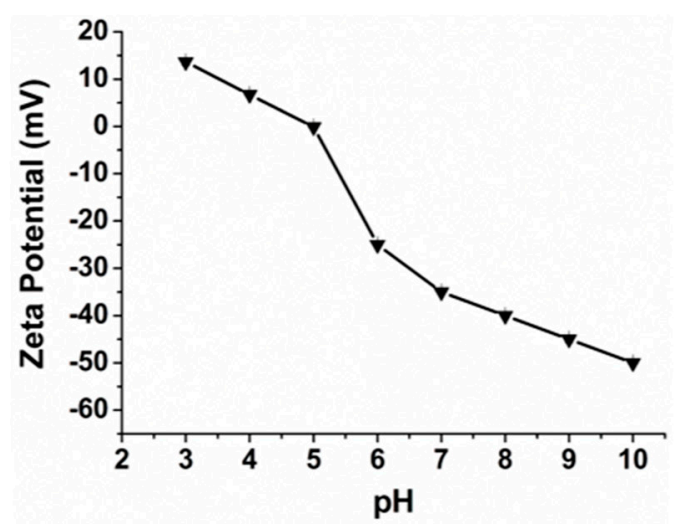

Figure 5. (a) Adsorption kinetics; (b) pseudo-second-order kinetic plot for $\mathrm{Hg}$ (II) adsorption; (c) Langmuir adsorption isotherms of uncoated $\mathrm{Fe}_{3} \mathrm{O}_{4}, \mathrm{C} @ F e_{3} \mathrm{O}_{4}$, and Cys-C@ $\mathrm{Fe}_{3} \mathrm{O}_{4} ;$ (d) effect of $\mathrm{pH}$ on $\mathrm{Hg}$ (II) adsorption by $500 \mathrm{Cys}-\mathrm{C}_{\mathrm{O}} \mathrm{Fe}_{3} \mathrm{O}_{4}$; (e) $\mathrm{Hg}$ ion speciation diagram with $\mathrm{pH}$ as simulated using the Visual MINTEQ 3.1 software $\left(\mathrm{C}_{\mathrm{Hg}}(\right.$ total $\left.)=1000 \mathrm{ppb}\right)$; and (f) zeta potential of 500Cys-C@ $\mathrm{Fe}_{3} \mathrm{O}_{4}$ particles at different $\mathrm{pH}$ values. Small standard deviations from five identical batch experiments shown in Figure 5a,d implied the high data reproducibility.

\subsection{Adsorption Isotherm}

The relationship between the equilibrated mercury uptake $\left(q_{\mathrm{e}}\right)$ of sorbent particles and the equilibrated concentration of $\mathrm{Hg}(\mathrm{II})$ in solution $\left(C_{\mathrm{e}}\right)$ was used to quantitatively describe the sorption, by way of adsorption isotherms. In this case, experiments were performed under conditions as used in the kinetic studies, but initial $\mathrm{Hg}$ (II) concentrations were varied from 60 to $1000 \mathrm{ppb}$. The adsorption time 
of $60 \mathrm{~min}$ is sufficient for adsorption-desorption equilibrium, as the difference in $\mathrm{Hg}$ (II) uptake from $60 \mathrm{~min}$ treatments and from longer treatment time was found negligible. As depicted in Figure $5 \mathrm{c}, \mathrm{Hg}$ (II) uptake increased with initial $\mathrm{Hg}$ (II) concentration until it reached a saturation point. According to these profiles, the saturated adsorption capacities of uncoated $\mathrm{Fe}_{3} \mathrm{O}_{4}, \mathrm{C}_{0} \mathrm{Fe}_{3} \mathrm{O}_{4}$, and 500Cys-C@ $\mathrm{Fe}_{3} \mathrm{O}_{4}$ were 12,28 , and $90 \mathrm{mg} \mathrm{g}^{-1}$, respectively. The equilibrium data were then fitted using the Langmuir model (Figure S3a), allowing prediction of equilibrium parameters [56].

$$
S_{a d}=N_{\max } \times\left(S_{a q} /\left(K^{-1}+S_{a q}\right)\right) .
$$

In Equation (4), $S_{a d}$ is the number of ions adsorbed per unit area of sorbent surface ( $\left.\mathrm{mg} \mathrm{g}^{-1}\right), S_{a q}$ is the equilibrium concentration of ions in solution $\left(\mathrm{mg} \mathrm{L}^{-1}\right), N_{\max }$ is the maximum adsorption capacity $\left(\mathrm{mg} \mathrm{g}^{-1}\right)$ corresponding to complete monolayer coverage on the sorbent surface, and $\mathrm{K}$ is the Langmuir adsorption constant $\left(\mathrm{L} \mathrm{mol}^{-1}\right)$ related to binding strength. From fitting results shown in Table 2 and comparisons with results calculated using the Freundlich model [15] (data shown in Figure S3b), adsorption clearly follows Langmuir behavior indicating formation of a uniform monolayer of metal ions adsorbed on the particle surface [50]. Furthermore, it is important to note that the calculated maximum adsorption capacity of uncoated $\mathrm{Fe}_{3} \mathrm{O}_{4}\left(12.56 \mathrm{mg} \mathrm{g}^{-1}\right)$ is enhanced by carbon coating $\left(29.85 \mathrm{mg} \mathrm{g}^{-1}\right)$ and more so, by cysteine functionalization $\left(94.33 \mathrm{mg} \mathrm{g}^{-1}\right)$.

Table 2. Adsorption isotherm parameters and sorption rate constants for $\mathrm{Hg}(\mathrm{II})$ adsorbed on uncoated $\mathrm{Fe}_{3} \mathrm{O}_{4}, \mathrm{C} @ \mathrm{Fe}_{3} \mathrm{O}_{4}$, and 500Cys-C@ $\mathrm{Fe}_{3} \mathrm{O}_{4}$.

\begin{tabular}{|c|c|c|c|}
\hline & Uncoated $\mathrm{Fe}_{3} \mathrm{O}_{4}$ & $\mathrm{C} @ \mathrm{Fe}_{3} \mathrm{O}_{4}$ & $500 \mathrm{Cys}-\mathrm{C} @ \mathrm{Fe}_{3} \mathrm{O}_{4}$ \\
\hline \multicolumn{4}{|l|}{ Langmuir model } \\
\hline $\begin{array}{c}q_{e(\exp )}\left(\mathrm{mg}^{-\mathrm{g}^{-1}}\right) \\
\text { Pseudo-first-order model }\end{array}$ & 12.27 & 21.01 & 90.03 \\
\hline$K_{1}\left(\min ^{-1}\right)$ & 0.028 & 0.034 & 0.041 \\
\hline$q_{e(c a l)}\left(\mathrm{mg} \mathrm{g}^{-1}\right)$ & 9.526 & 7.874 & 35.07 \\
\hline$R^{2}$ & 0.986 & 0.945 & 0.601 \\
\hline \multicolumn{4}{|l|}{ Pseudo-second-order model } \\
\hline$K_{2}\left(\mathrm{~g} \cdot \mathrm{mg}^{-1} \cdot \mathrm{min}^{-1}\right)$ & 0.007 & 0.014 & 0.004 \\
\hline$q_{e(c a l)}\left(\mathrm{mg} \cdot \mathrm{g}^{-1}\right)$ & 13.95 & 22.03 & 95.24 \\
\hline$R^{2}$ & 0.998 & 0.998 & 0.995 \\
\hline \multicolumn{4}{|l|}{ Freundlich model } \\
\hline$K_{f}\left(\mathrm{mg} \cdot \mathrm{g}^{-1}\right)$ & 11.12 & 35.11 & 265.58 \\
\hline$n$ & 7.41 & 3.86 & 1.98 \\
\hline$R^{2}$ & 0.8212 & 0.9626 & 0.9100 \\
\hline
\end{tabular}

\subsection{Effect of $\mathrm{pH}$ on $\mathrm{Hg}(\mathrm{II})$ Adsorption}

Figure $5 \mathrm{a}$, d both showed that the $\mathrm{Hg}$ uptake reached maximum $\mathrm{Hg}$ (II) uptake values after $20 \mathrm{~min}$. Figure $5 \mathrm{~d}$ shows the effect of $\mathrm{pH}$ on $\mathrm{Hg}$ (II) adsorption by $500 \mathrm{Cys}-\mathrm{C} @ \mathrm{Fe}_{3} \mathrm{O}_{4}$, revealing that removal capacity is highly $\mathrm{pH}$ dependent. The aqueous formation of charged $\mathrm{Hg}(\mathrm{II})$ species $\left(\mathrm{Hg}^{2+}, \mathrm{HgOH}^{+}\right)$ and neutral $\mathrm{Hg}(\mathrm{OH})_{2}$ can result at different $\mathrm{pH}$ values, although these are all capable of reacting with L-cysteine thiol groups due to the high affinity of $\mathrm{Hg}$ for sulfur [31]. As shown in Figure 5e, speciation curves calculated using the Visual MINTEQ software [26] indicate that free $\mathrm{Hg}$ (II) ions predominate at $\mathrm{pH} \leq 2$, which in the presence of thiol groups may form positively charged complexes $\left(\mathrm{S}-\mathrm{Hg}^{+}\right)$. The presence of large numbers of such complexes on the sorbent surface may, at some point, inhibit further binding based on electrostatic repulsion. At higher $\mathrm{pH}$ values mercuric hydroxide species $\left(\mathrm{HgOH}^{+}\right.$and $\left.\left.\mathrm{Hg}(\mathrm{OH})_{2}\right)\right)$ become more prevalent, which are able to bind to cysteine thiol groups forming neutral complexes $(-\mathrm{S}-\mathrm{HgOH})$ [57]. The buildup of uncharged $\mathrm{Hg}$ (II) complexes on the sorbent surface does not retard further $\mathrm{Hg}$ (II) adsorption in the same way as accumulation of positive charge. Accordingly, $500 \mathrm{Cys}-\mathrm{C} @ \mathrm{Fe}_{3} \mathrm{O}_{4}$ exhibits greater $\mathrm{Hg}$ (II) removal performance at higher 
$\mathrm{pH}$ values, as shown in Figure $5 \mathrm{~d}$. These findings are in agreement with zeta potential measurements with 500Cys-C@ $\mathrm{Fe}_{3} \mathrm{O}_{4}$ (Figure 5f), which indicate that the particle surface is positively charged at a solution $\mathrm{pH}$ lower than the Point Zero Charge $(P Z C, \sim 5.4)$ and becomes negatively charged only above this value.

\subsection{Adsorption of $\mathrm{Hg}(\mathrm{II})$ at Ultralow Concentrations}

To further demonstrate the efficiency of $500 \mathrm{Cys}-\mathrm{C} @ \mathrm{Fe}_{3} \mathrm{O}_{4}$ for $\mathrm{Hg}$ (II) removal, adsorption studies were conducted using ultralow $\mathrm{Hg}$ (II) concentrations. Adsorption experiments using $\mathrm{Hg}$ (II) concentrations ranging from 100 to $5 \mathrm{ppb}\left(\mathrm{pH}\right.$ 6) demonstrated the performance of $500 \mathrm{Cys}-\mathrm{C} @ \mathrm{Fe}_{3} \mathrm{O}_{4}$, with $>99 \% \mathrm{Hg}$ (II) removal being possible in $1 \mathrm{~h}$ over the entire concentration range, from 100, 50, 20, 10 , and $5 \mathrm{ppb}$ to $0.86,0.45,0.36,0.34$, and $0.31 \mathrm{ppb}$, respectively. These final $\mathrm{Hg}$ (II) concentrations were less than $1 \mathrm{ppb}$, meeting acceptable limits for drinking water set down by the WHO and EU [8].

\subsection{Selectivity of 500Cys-C@Fe $\mathrm{O}_{4}$ Sorbent}

Many types of metal ions coexist in real water samples; competitive binding of these with $\mathrm{Hg}$ (II) to sorbents is, therefore, a serious issue potentially governing sorbent performance. In this work, three contaminant metal ions commonly found in industrial wastewater [58,59], $\mathrm{Cu}(\mathrm{II}), \mathrm{Pb}$ (II), and $\mathrm{Ni}(\mathrm{II})$, were selected as the basis for competitive adsorption studies against $\mathrm{Hg}$ (II) using $500 \mathrm{Cys}-\mathrm{C} @ \mathrm{Fe}_{3} \mathrm{O}_{4}$. As seen in Table 3, these ions have negligible effect towards the adsorption of $\mathrm{Hg}$ (II). This can be rationalized using the Hard-Soft Acid-Base (HSAB) theory: $\mathrm{Hg}$ (II) is considered as a soft metal (relatively large ionic size, low electronegativity, and high polarizability) with higher affinity for soft donor atoms (such as sulfur) than relatively hard metal ions ( $\mathrm{Cu}(\mathrm{II}), \mathrm{Pb}(\mathrm{II})$, and $\mathrm{Ni}(\mathrm{II}))$ [60].

Table 3. Concentrations of $\mathrm{Hg}(\mathrm{II}) \mathrm{Pb}(\mathrm{II}), \mathrm{Ni}(\mathrm{II})$, and $\mathrm{Cu}(\mathrm{II})$ ions in a simulated wastewater before and after treatment with 500Cys-C@ $\mathrm{Fe}_{3} \mathrm{O}_{4}$ sorbent. The concentrations of each metal ion in the treated wastewater shows the amount of residual metal contaminants after adsorption.

\begin{tabular}{ccccc}
\hline & \multicolumn{4}{c}{ Metal Ion Concentration (ppb) } \\
\cline { 2 - 5 } & $\mathbf{H g}(\mathrm{II})$ & $\mathbf{P b}(\mathrm{II})$ & $\mathbf{N i ( I I )}$ & $\mathbf{C u}(\mathrm{II})$ \\
\hline Before adsorption & 1000.0 & 500.8 & 505.3 & 501.3 \\
After adsorption & 105.4 & 495.6 & 497.7 & 494.4 \\
\hline Removal efficiency & $89.5 \%$ & $1.0 \%$ & $1.5 \%$ & $1.3 \%$ \\
\hline
\end{tabular}

\subsection{Determination of Thermodynamic Parameters}

To study the thermodynamics of $\mathrm{Hg}(\mathrm{II})$ adsorption, a series of adsorption tests were performed, each using $1.0 \mathrm{mg}$ of $500 \mathrm{Cys}-\mathrm{C} @ \mathrm{Fe}_{3} \mathrm{O}_{4}$ with $100 \mathrm{~mL}$ of $1000 \mathrm{ppb} \mathrm{Hg}(\mathrm{II})$ solution at different temperatures $\left(25,35\right.$, or $\left.40^{\circ} \mathrm{C}\right)$. The thermodynamic feasibility and spontaneous nature of the adsorption process were assessed based on thermodynamic parameters including the standard Gibbs free energy $\left(\Delta \mathrm{G}^{\circ}\right)$, enthalpy change $\left(\Delta \mathrm{H}^{\circ}\right)$, and entropy change $\left(\Delta \mathrm{S}^{\circ}\right)$, as determined from the following equations $[54,55,57]$.

$$
\begin{gathered}
\Delta \mathrm{G}^{\circ}=-\mathrm{RT} \ln K_{\mathrm{d}} \\
\ln K_{\mathrm{d}}=\left(\Delta \mathrm{S}^{\circ} / \mathrm{R}\right)-\left(\Delta \mathrm{H}^{\circ} / \mathrm{RT}\right) \\
K_{\mathrm{d}}=q_{\mathrm{e}} / C_{\mathrm{e}},
\end{gathered}
$$

where $K_{\mathrm{d}}$ is the distribution coefficient of adsorption, $\mathrm{R}$ is the universal gas constant $\left(8.314 \mathrm{~J} \cdot \mathrm{mol}^{-1} \cdot \mathrm{K}^{-1}\right)$, and $\mathrm{T}$ is the absolute temperature $(\mathrm{K}) \cdot q_{\mathrm{e}}$ and $C_{\mathrm{e}}$ are the mercury uptake and equilibrium concentration of mercury (mg. $\mathrm{L}^{-1}$ ) after adsorption, respectively (see Experimental section). Values of $\Delta \mathrm{H}^{\circ}$ $\left(-24.1 \mathrm{~kJ} \mathrm{~mol}^{-1}\right)$ and $\Delta \mathrm{S}^{\circ}\left(-72.7 \mathrm{~J} \mathrm{~mol}^{-1} \mathrm{~K}^{-1}\right)$ were quantified from the slope and intercept of the linear van't Hoff plot, as seen in Figure S4. The values of $\Delta \mathrm{G}^{\circ}\left(-2.93 \mathrm{~kJ} \mathrm{~mol}^{-1}\right.$ at $298 \mathrm{~K},-1.70 \mathrm{~kJ} \mathrm{~mol}^{-1}$ at $308 \mathrm{~K}$, 
and $-1.27 \mathrm{~kJ} \mathrm{~mol}^{-1}$ at $313 \mathrm{~K}$ ) suggest that $\mathrm{Hg}(\mathrm{II})$ adsorption on the cysteine functionalized carbon-coated magnetite is thermodynamically feasible. The decrease in $-\Delta \mathrm{G}^{\circ}$ with increasing temperature reveals that the sorption process is exothermic and more favorable at lower temperatures, similar to previous work [15,55]. Joen et al. [61] has suggested that escape of mercury ions from surface sites is more facile at higher temperature. The negative value of $\Delta \mathrm{H}^{\circ}$ indicates that $\mathrm{Hg}$ (II) sorption is exothermic at $25-40{ }^{\circ} \mathrm{C}$. The value of $\Delta \mathrm{S}^{\circ}$ is also negative, suggesting a decrease in randomness at the solid/solution interface during $\mathrm{Hg}(\mathrm{II})$ sorption.

\subsection{Sorbent Recyclability}

As shown in the Figure 6 inset, 500Cys-C@ $\mathrm{Fe}_{3} \mathrm{O}_{4}$ sorbent can be well dispersed in aqueous media and can be harvested easily by magnetic separation. Desorption of $\mathrm{Hg}$ (II) from the sorbent surface was examined to provide a measure of sorbent stability and recyclability, both being important parameters for industrial applications. For 500Cys- $\mathrm{C} @ \mathrm{Fe}_{3} \mathrm{O}_{4}$, experiments were conducted using an eluent solution $(10 \mathrm{~mL})$ composed of $0.1 \mathrm{M} \mathrm{HCl}$ and $5 \%(\mathrm{w} / \mathrm{v})$ thiourea. Prior to measurements, the used sorbent was washed three times with deionized water. After adding the eluent solution to the used sorbent, desorption was allowed to proceed by shaking the suspension for $1 \mathrm{~h}$ at a constant temperature. It is possible that dissolution of magnetite particles could occur during desorption under the experimental conditions. Atomic absorption spectroscopy of the eluent solution after the first desorption cycle indicated an Fe concentration of $0.34 \mathrm{ppm}$ for $500 \mathrm{Cys}-\mathrm{C} @ \mathrm{Fe}_{3} \mathrm{O}_{4}$, and $0.51 \mathrm{ppm}$ and $5.94 \mathrm{ppm}$ for $\mathrm{C}_{\mathrm{Fe}} \mathrm{O}_{4}$ and uncoated $\mathrm{Fe}_{3} \mathrm{O}_{4}$ nanoparticles, respectively, highlighting the importance of the surface coating on maintaining core integrity. Results of desorption and adsorption for five cycles using the 500Cys-C@ $\mathrm{Fe}_{3} \mathrm{O}_{4}$ sorbent are shown in Figure 6. These reveal that the sorbent maintains high desorption efficiency $(90 \%)$ and $\mathrm{Hg}$ uptake $\left(90 \mathrm{mg} \cdot \mathrm{g}^{-1}\right)$ performance over the first three cycles. However, adsorption efficiencies significantly decreased for the fourth and fifth cycles, while the desorption efficiency only slightly decreased. This behavior could result from saturation of the binding sites and/or degradation of bound cysteine moieties at low $\mathrm{pH}[62,63]$.

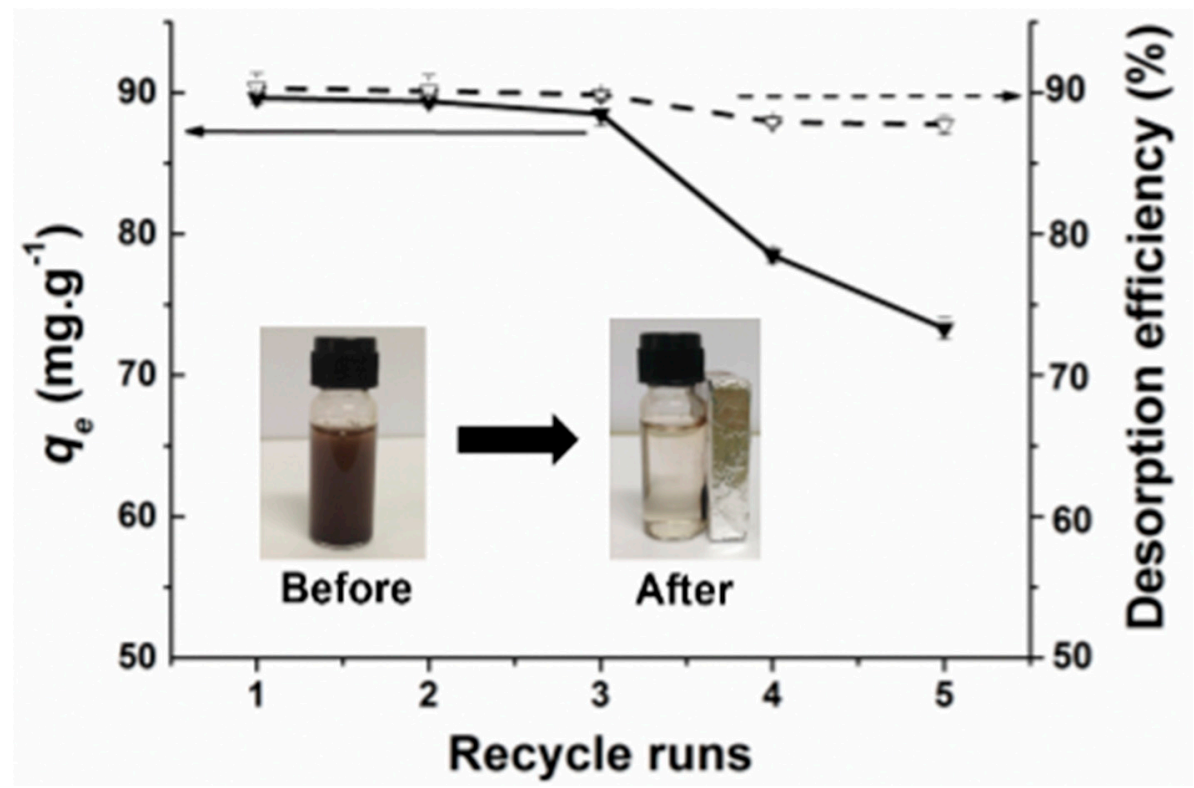

Figure 6. $\mathrm{Hg}$ (II) uptake (solid line) and percentage $\mathrm{Hg}$ (II) desorbed (dashed line) over five adsorption/ desorption cycles using $500 \mathrm{Cys}-\mathrm{C} @ \mathrm{Fe}_{3} \mathrm{O}_{4}$ sorbent. The inset shows the separation of the material from the aqueous media using an external magnetic field.

Table 4 highlights examples of sorbents applied to removal of ultralow concentrations $(<20 \mathrm{ppb}$ of $\mathrm{Hg}(\mathrm{II}))$, in comparison to 500Cys-C@ $\mathrm{Fe}_{3} \mathrm{O}_{4}$ material. From these, 500Cys-C@ $\mathrm{Fe}_{3} \mathrm{O}_{4}$ shows comparable performance at much lower sorbent loadings, although longer contact times were employed in 
this work. Thio-silica-coated magnetite required very low sorbent loadings for $\mathrm{Hg}(\mathrm{II})$ removal, but its preparation is more complex, requiring more steps than that needed for $\mathrm{Cys}-\mathrm{C} @ \mathrm{Fe}_{3} \mathrm{O}_{4}$ [15]. Acrylamide-hydroxyl-MOFs [10] and MOF-74-Zn [16] show lower removal efficiencies using higher sorbent loadings and are nonmagnetic, thus cannot be separated for reuse by an application of an external magnet. Furthermore, the adsorption capacity and satisfactory level of sorbent performance in removal of ultralow concentrations of $\mathrm{Hg}(\mathrm{II})$ based on the WHO and EU drinking water standards is reported in Table 5, in which 500Cys-C@ $\mathrm{Fe}_{3} \mathrm{O}_{4}$ material shows superior comparative performance at low sorbent loadings.

Table 4. Comparison of adsorption capacities of sorbents towards $\mathrm{Hg}$ (II) removal from dilute aqueous metal solutions (100 $\mathrm{ppb} \geq(\mathrm{Hg}(\mathrm{II}))$.

\begin{tabular}{|c|c|c|c|c|}
\hline Sorbent & $\begin{array}{l}\text { Concentration } \\
(p p b)\end{array}$ & $\begin{array}{l}\text { Loading } \\
\left(\mathrm{g} . \mathrm{L}^{-1}\right)\end{array}$ & $\begin{array}{l}\text { Contact Time } \\
\quad(\mathrm{min})\end{array}$ & $\begin{array}{l}\text { Removal } \\
\text { Efficiency }\end{array}$ \\
\hline Cys-C@ $@ \mathrm{Fe}_{3} \mathrm{O}_{4}$ (this work) & $\begin{array}{c}5-100 \\
1000\end{array}$ & $\begin{array}{l}0.01 \\
0.01\end{array}$ & $\begin{array}{l}60 \\
10\end{array}$ & $\begin{array}{c}94-99.4 \% \\
90 \%\end{array}$ \\
\hline $\begin{array}{l}\text { 2-mercapto-benzothiazole } \\
\mathrm{Fe}_{3} \mathrm{O}_{4} \text { composite [13] }\end{array}$ & $5-200$ & 1.00 & 4 & $92-99 \%$ \\
\hline $\begin{array}{c}\mathrm{N}\left(\mathrm{CH}_{2} \mathrm{COOH}\right)_{2} \text { containing } \\
\text { polymer } / \mathrm{Fe}_{3} \mathrm{O}_{4} \text { composite [12] }\end{array}$ & $5-50$ & 0.40 & 10 & $\sim 98 \%$ \\
\hline Magnetic powdered activated carbon [14] & 100 & 1.00 & 180 & $84 \%$ \\
\hline Thiol-silica-coated magnetite [15] & 80 & 0.008 & 15 & $100 \%$ \\
\hline Acrylamide-hydroxyl-MOFs [10] & 100 & 0.05 & 60 & $80 \%$ \\
\hline MOF-74-Zn [16] & $20-50$ & 0.10 & 120 & $54-72.3 \%$ \\
\hline
\end{tabular}

Comparative PC values of 500 Cys- $\mathrm{C} @ \mathrm{Fe}_{3} \mathrm{O}_{4}$ material, at varying initial $\mathrm{Hg}$ (II) concentrations (5-1000 ppb), were evaluated using Equation (2). They are reported in Table 5. The obtained PC values of the developed magnetic material at the studied $\mathrm{Hg}$ (II) concentration range were found being much higher than other sorbents. In particular, the significantly high PC values of the $\mathrm{Cys}-\mathrm{C}_{\mathrm{Fe}} \mathrm{O}_{4}$ material at ultralow $\mathrm{Hg}(\mathrm{II})$ initial concentrations ( $\leq 20 \mathrm{ppb}$ ) should be attributed to the high chelating ability of $\mathrm{Hg}(\mathrm{II})$ ions and the $-\mathrm{NH}_{2}$ and $-\mathrm{SH}$ functional groups present on the surface of magnetic material. 
Table 5. Comparative sorption capacities, $\mathrm{Hg}$ concentrations before and after treatment, $\mathrm{Hg}$ uptake, and partition coefficient values for various sorbents for $\mathrm{Hg}$ (II) removal at ultralow metal concentrations. The numbers in bold indicate the $\mathrm{Hg}$ (II) concentration lower than the World Health Organization (WHO) and European Union (EU) permissible limits of total mercury in drinking water. Note that n.d. is denoted as not determined as the volume of treated Hg(II) solution is unknown, while n.a is denoted as not applied due to the partition coefficient (PC) value is infinity using Equation (3).

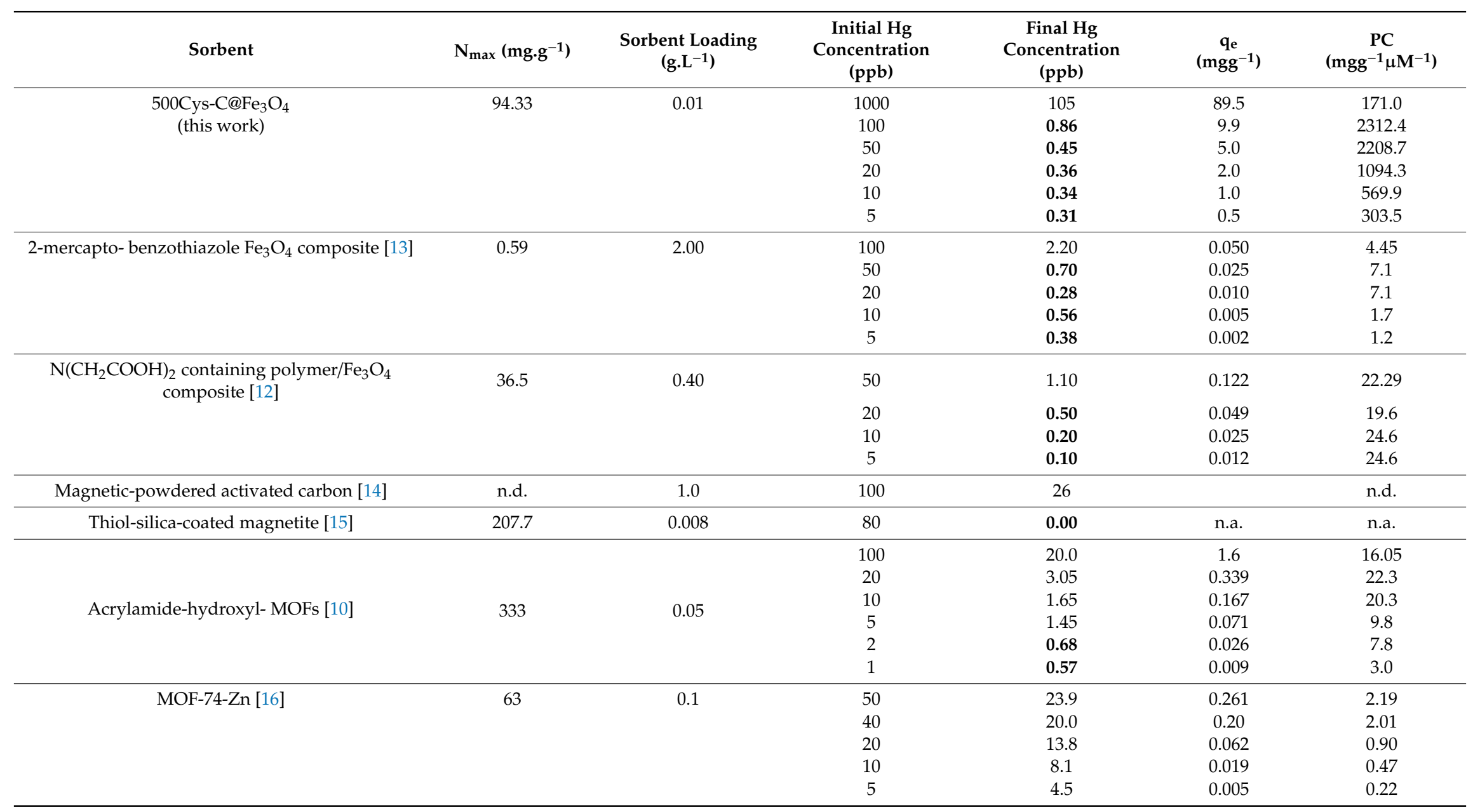




\section{Conclusions}

Efficient $\mathrm{Hg}$ (II) sorbents based on magnetite particles have been prepared using a simple synthetic procedure from low-cost materials; cost per kilogram [64] was urea (USD \$0.2), L-cysteine (USD \$10), D-Glucose (USD \$0.4), ethylene glycol (USD \$0.5), and hydrated ferric chloride (USD $\$ 0.65)$. Utilizing cysteine as a functionalization reagent for magnetic sorbents is much more economic and simpler, compared with productions of functionalized magnetic sorbents via multistep material synthesis $[12,13,15]$, expensive functionalization reagent, or high-purity chemicals $[10,12,13,15,16]$. These sorbents are easy to separate from aqueous media and demonstrate excellent recyclability metrics.

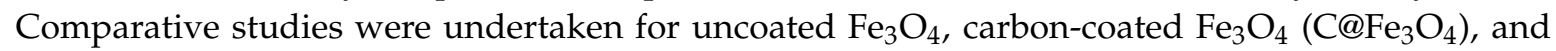
cysteine-functionalized carbon-coated $\mathrm{Fe}_{3} \mathrm{O}_{4}\left(\mathrm{Cys}-\mathrm{C} @ \mathrm{Fe}_{3} \mathrm{O}_{4}\right)$ sorbent particles. The 500Cys-C@ $\mathrm{Fe}_{3} \mathrm{O}_{4}$ sorbent, having optimum L-cysteine loadings, are highly selective for $\mathrm{Hg}$ (II) adsorption, are capable of removing $90 \%$ of $\mathrm{Hg}(\mathrm{II})$ within $10 \mathrm{~min}$, and are effective even at ultralow metal concentrations. The carbon shell enhances the $\mathrm{Hg}$ (II) sorption capacity, preserves the integrity of the $\mathrm{Fe}_{3} \mathrm{O}_{4}$ core, and acts as a scaffold, allowing appendage of metal chelating L-cysteine to the particle surface. Surface modification of $\mathrm{C} @ \mathrm{Fe}_{3} \mathrm{O}_{4}$ by cysteine boosts the performance and selectivity of the materials, resulting in enhanced levels of $\mathrm{Hg}$ (II) removal with fast adsorption rates, at ultralow $\mathrm{Hg}$ (II) concentrations. Moreover, factors potentially influencing adsorption efficiency, such as $\mathrm{pH}$ and temperature, were comprehensively studied in respect to both kinetics and thermodynamics. The facile preparation, fast and impressive adsorption performance, good selectivity, ease of separation, and recyclability alludes to the high potential of $\mathrm{Cys}-\mathrm{C} @ \mathrm{Fe}_{3} \mathrm{O}_{4}$ as a candidate for selective removal of $\mathrm{Hg}(\mathrm{II})$ contaminants from water sources and for its possible adoption in mainstream water treatment processes.

Supplementary Materials: The following are available online at http://www.mdpi.com/2076-3417/10/22/8262/s1, Table S1 \%Breakthrough (BT, of \%removal efficiency) and BT time interpolated from the \%BT vs. treatment times plot in Figure 4, Table S2: \%Breakthrough (BT, of \%removal efficiency) and BT time interpolated from the \%BT vs. treatment times plotted in Figure S2., Scheme S1: Synthesis process for uncoated $\mathrm{Fe}_{3} \mathrm{O}_{4}, \mathrm{C} \mathrm{Fe}_{3} \mathrm{O}_{4}$, and Cys-C@ $\mathrm{Fe}_{3} \mathrm{O}_{4}$ samples. Figure S1: Nitrogen adsorption-desorption isotherms and pore size distribution plots (inset) for (a) uncoated $\mathrm{Fe}_{3} \mathrm{O}_{4}$, (b) $\mathrm{C} @ \mathrm{Fe}_{3} \mathrm{O}_{4}$, (c) 250Cys-C@ $\mathrm{Fe}_{3} \mathrm{O}_{4}$, (d) $500 \mathrm{Cys}-\mathrm{C} @ \mathrm{Fe}_{3} \mathrm{O}_{4}$, and (e)1000Cys-C@ $\mathrm{Fe}_{3} \mathrm{O}_{4}$. Figure S2: $\mathrm{Hg}$ (II) treatment time dependence of \% Breakthrough (BT) at initial $\mathrm{Hg}$ (II) concentration of $1000 \mathrm{ppb}$ and sorbent loading of $0.01 \mathrm{~g} \mathrm{~L}^{-1}$ at different $\mathrm{pH}$ values. High reproducibility of the measurements can be indicated by small standard deviations from five identical batch experiments. Figure S3: Linear fitting of (a) Langmuir and (b) Freundlich isotherms for $\mathrm{Hg}(\mathrm{II})$ adsorption onto uncoated $\mathrm{Fe}_{3} \mathrm{O}_{4}, \mathrm{C} @ \mathrm{Fe}_{3} \mathrm{O}_{4}$, and 500Cys-C@ $\mathrm{Fe}_{3} \mathrm{O}_{4}$ and thermodynamic data for $\mathrm{Hg}$ (II) adsorption on 500Cys-C@ $\mathrm{Fe}_{3} \mathrm{O}_{4}$. Figure S4: Thermodynamic data for $\mathrm{Hg}$ (II) adsorption on 500Cys-C@ $\mathrm{Fe}_{3} \mathrm{O}_{4}$.

Author Contributions: Formal analysis, investigation, and writing-original draft preparation, A.S. Formal analysis, investigation, and writing-original draft preparation, T.B. Formal analysis, investigation, W.P.-O. Conceptualization, methodology, and supervision, T.S., K.U., and K.S. Writing-review and editing, S.C. Project administration, conceptualization, methodology, funding acquisition, and writing-review and editing, S.M.S. All authors have read and agreed to the published version of the manuscript.

Funding: This research was partially funded by the Thailand Science Research and Innovation (grant no. IRN62W0005). A.S. received the scholarship from the Royal Golden Jubilee Ph.D. Program (grant no. PHD/0119/2553).

Acknowledgments: The authors acknowledge financial support from the Thailand Science Research and Innovation through the Royal Golden Jubilee Ph.D. Program (grant no. PHD/0119/2553) and research grants (IRN62W0005). Instruments were provided by PTT Public Company Limited, Center of Excellence for Innovation in Chemistry (PERCH-CIC), and the Faculty of Science, Mahidol University.

Conflicts of Interest: The authors declare no conflicts of interest.

\section{References}

1. Jiang, G.-B.; Shi, J.B.; Feng, X.-B. Mercury pollution in China. An overview of the past and current sources of the toxic metal. Environ. Sci. Technol. 2006, 40, 3672-3678. [CrossRef]

2. Weisener, C.G.; Sale, K.S.; Smyth, D.J.A.; Blowes, D.W. Field column study using zerovalent iron for mercury removal from contaminated groundwater. Environ. Sci. Technol. 2005, 39, 6306-6312. [CrossRef] 
3. Herrero, R.; Lodeiro, P.; Rey-Castro, C.; Vilariño, T.; Sastre de Vicente, M.E. Removal of inorganic mercury from aqueous solutions by biomass of the marine macroalga Cystoseira baccata. Water Res. 2005, 39, 3199-3210. [CrossRef] [PubMed]

4. Vikrant, K.; Kim, K.H. Nanomaterials for the adsorptive treatment of $\mathrm{Hg}(\mathrm{II})$ ions from water. Chem. Eng. J. 2019, 358, 264-282. [CrossRef]

5. Azimi, A.; Azari, A.; Rezakazemi, M.; Ansarpour, M. Removal of Heavy Metals from Industrial Wastewaters: A Review. ChemBioEng Rev. 2017, 4, 37-59. [CrossRef]

6. Bernhoft, R.A. Mercury toxicity and treatment: A review of the literature. J. Environ. Public Health 2012, 460508. [CrossRef] [PubMed]

7. United Nations Environment Program. Practical Sourcebook on Mercury Waste Storage and Disposal; United Nations Environmental Program: Nairobi, Kenya, 2015.

8. The World Health Organization (WHO). Guidelines for Drinking-Water Quality, 3rd ed.; Directive 2000/60/EC of the European Parliament and of the Council; WHO: Geneva, Switzerland, 2000.

9. De Clercq, J. Removal of mercury from aqueous solutions by adsorption on a new ultra stable mesoporous adsorbent and on a commercial ion exchange resin. Int. J. Ind. Chem. 2012, 3, 13. [CrossRef]

10. Luo, F.; Chen, J.L.; Dang, L.L.; Zhou, W.N.; Lin, H.L.; Li, J.Q.; Liu, S.J.; Luo, M.B. High-performance $\mathrm{Hg}^{2+}$ removal from ultra-low-concentration aqueous solution using both acylamide- and hydroxyl-functionalized metal-organic framework. J. Mater. Chem. A 2015, 3, 9616-9620. [CrossRef]

11. Qu, Z.; Yan, L.; Li, L.; Xu, J.; Liu, M.; Li, Z.; Yan, N. Ultraeffective ZnS nanocrystals sorbent for mercury(II) Removal Based on Size-Dependent Cation Exchange. ACS Appl. Mater. Interfaces 2014, 6, 18026-18032. [CrossRef]

12. Qi, X.; Li, N.; Xu, Q.; Chen, D.; Li, H.; Lu, J. Water-soluble $\mathrm{Fe}_{3} \mathrm{O}_{4}$ superparamagnetic nanocomposites for the removal of low concentration mercury(II) ions from water. RSC Adv. 2014, 4, 47643-47648. [CrossRef]

13. Parham, H.; Zargar, B.; Shiralipour, R. Fast and efficient removal of mercury from water samples using magnetic iron oxide nanoparticles modified with 2-mercaptobenzothiazole. J. Hazard. Mater. 2012, 205, 94-100. [CrossRef] [PubMed]

14. Faulconer, E.K.; von Reitzenstein, N.V.H.; Mazyck, D.W. Optimization of magnetic powdered activated carbon for aqueous $\mathrm{Hg}$ (II) removal and magnetic recovery. J. Hazard. Mater. 2012, 199-200, 9-14. [CrossRef] [PubMed]

15. Hakami, O.; Zhang, Y.; Banks, C.J. Thiol-functionalised mesoporous silica-coated magnetite nanoparticles for high efficiency removal and recovery of $\mathrm{Hg}$ from water. Water Res. 2012, 46, 3913-3922. [CrossRef] [PubMed]

16. Xiong, Y.Y.; Li, J.Q.; Gong, L.L.; Feng, X.F.; Meng, L.N.; Zhang, L.; Meng, P.P.; Luo, M.B.; Luo, F. Using MOF-74 for $\mathrm{Hg}^{2+}$ removal from ultra-low concentration aqueous solution. J. Solid State Chem. 2017, 246, 16-22. [CrossRef]

17. Luo, H.; Zhang, S.; Li, X.; Liu, X.; Xu, Q.; Liu, J.; Wang, Z. Tannic acid modified $\mathrm{Fe}_{3} \mathrm{O}_{4}$ core-shell nanoparticles for adsorption of $\mathrm{Pb}^{2+}$ and $\mathrm{Hg}^{2+}$. J. Taiwan Inst. Chem. Eng. 2017, 72, 163-170. [CrossRef]

18. Azari, A.; Gharibi, H.; Kakavandi, B.; Ghanizadeh, G.; Javid, A.; Hossein Mahvi, A.; Sharafia, K.; Khosravia, T. Magnetic adsorption separation process: An alternative method of mercury extracting from aqueous solution using modified chitosan coated $\mathrm{Fe}_{3} \mathrm{O}_{4}$ nanocomposites. J. Chem. Technol. Biotechnol. 2017, 92, 188-200. [CrossRef]

19. Kazemi, A.; Bahramifar, N.; Heydari, A.; Olsen, S.I. Synthesis and sustainable assessment of thiol-functionalization of magnetic graphene oxide and superparamagnetic $\mathrm{Fe}_{3} \mathrm{O}_{4} @ \mathrm{SiO}_{2}$ for $\mathrm{Hg}$ (II) removal from aqueous solution and petrochemical wastewater. J. Taiwan Inst. Chem. Eng. 2019, 95, 78-93. [CrossRef]

20. Zhang, Z.; Niu, Y.; Chen, H.; Yang, Z.; Bai, L.; Xue, Z.; Yang, H. Feasible one-pot sequential synthesis of aminopyridine functionalized magnetic $\mathrm{Fe}_{3} \mathrm{O}_{4}$ hybrids for robust capture of aqueous $\mathrm{Hg}(\mathrm{II})$ and $\mathrm{Ag}(\mathrm{I})$. ACS Sustain. Chem. Eng. 2019, 7, 7324-7337. [CrossRef]

21. Zhou, Y.; Luan, L.; Tang, B.; Niu, Y.; Qu, R.; Liu, Y.; Xu, W. Fabrication of Schiff base decorated PAMAM dendrimer/magnetic $\mathrm{Fe}_{3} \mathrm{O}_{4}$ for selective removal of aqueous $\mathrm{Hg}(\mathrm{II})$. Chem. Eng. J. 2020, 398, 125651. [CrossRef]

22. Fayazi, M. Removal of mercury(II) from wastewater using a new and effective composite: Sulfur-coated magnetic carbon nanotubes. Environ. Sci. Pollut. Res. 2020, 27, 12270-12279. [CrossRef]

23. Jeon, C.; Solis, K.L.; An, H.-R.; Hong, Y.; Igalavithana, A.D.; Ok, Y.S. Sustainable removal of $\mathrm{Hg}$ (II) by sulfur-modified pine-needle biochar. J. Hazard. Mater. 2020, 388, 122048. [CrossRef] [PubMed]

24. Xu, X.; Schierz, A.; Xu, N.; Cao, X. Comparison of the characteristics and mechanisms of Hg(II) sorption by biochars and activated carbon. J. Colloid Interface Sci. 2016, 463, 55-60. [CrossRef]

25. Wang, Y.; Mu, Y.; Zhao, Q.-B.; Yu, H.-Q. Isotherms, kinetics and thermodynamics of dye biosorption by anaerobic sludge. Sep. Purif. Technol. 2006, 50,1-7. [CrossRef] 
26. Tang, X.; Niu, D.; Bi, C.; Shen, B. $\mathrm{Hg}^{2+}$ Adsorption from a low-concentration aqueous solution on chitosan beads modified by combining polyamination with $\mathrm{Hg} 2+$-imprinted technologies. Ind. Eng. Chem. Res. 2013, 52, 13120-13127. [CrossRef]

27. Tang, S.C.N.; Lo, I.M.C. Magnetic nanoparticles: Essential factors for sustainable environmental applications. Water Res. 2013, 47, 2613-2632. [CrossRef] [PubMed]

28. Cheng, K.; Zhou, Y.-M.; Sun, Z.-Y.; Hu, H.-B.; Zhong, H.; Kong, X.-K.; Chen, Q.-W. Synthesis of carbon-coated, porous and water-dispersive $\mathrm{Fe}_{3} \mathrm{O}_{4}$ nanocapsules and their excellent performance for heavy metal removal applications. Dalton Trans. 2012, 41, 5854-5861. [CrossRef]

29. Xuan, S.; Hao, L.; Jiang, W.; Gong, X.; Hu, Y.; Chen, Z. A facile method to fabricate carbon-encapsulated $\mathrm{Fe}_{3} \mathrm{O}_{4}$ core/shell composites. Nanotechnology 2007, 18, 035602. [CrossRef]

30. Peniche, H.; Osorio, A.; Acosta, N.; de la Campa, A.; Peniche, C. Preparation and characterization of superparamagnetic chitosan microspheres: Application as a support for the immobilization of tyrosinase. J. Appl. Polym. Sci. 2005, 98, 651-657. [CrossRef]

31. Pan, B.-F.; Gao, F.; Gu, H.-C. Dendrimer modified magnetite nanoparticles for protein immobilization. J. Colloid Interface Sci. 2005, 284, 1-6. [CrossRef]

32. Zhao, W.; Gu, J.; Zhang, L.; Chen, H.; Shi, J. Fabrication of uniform magnetic nanocomposite spheres with a magnetic core/mesoporous silica shell structure. J. Am. Chem. Soc. 2005, 127, 8916-8917. [CrossRef]

33. Shen, X.; Wang, Q.; Chen, W.; Pang, Y. One-step synthesis of water-dispersible cysteine functionalized magnetic Fe3O4 nanoparticles for mercury(II) removal from aqueous solutions. Appl. Surface Sci. 2014, 317, 1028-1034. [CrossRef]

34. Zheng, J.; Liu, Z.Q.; Zhao, X.S.; Liu, M.; Liu, X.; Chu, W. One-step solvothermal synthesis of Fe3O4@C core-shell nanoparticles with tunable sizes. Nanotechnology 2012, 23, 165601. [CrossRef] [PubMed]

35. Wang, H.; Yu, Y.-F.; Chen, Q.-W.; Cheng, K. Carboxyl-functionalized nanoparticles with magnetic core and mesopore carbon shell as adsorbents for the removal of heavy metal ions from aqueous solution. Dalton Trans. 2011, 40, 559-563. [CrossRef] [PubMed]

36. Liu, Q.; Li, W.; Zhao, W.; Tan, L.; Jing, X.; Liu, J.; Song, D.; Zhang, H.; Li, R.; Liu, L.; et al. Synthesis of ketoxime-functionalized Fe3O4@C core-shell magnetic microspheres for enhanced uranium(VI) removal. RSC Adv. 2016, 6, 22179-22186. [CrossRef]

37. Azam, A.S.; Mohammad, A.A. Magnetic $\mathrm{Fe}_{3} \mathrm{O}_{4} @ \mathrm{C}$ nanoparticles modified with 1-(2-thiazolylazo)-2-naphthol as a novel solid-phase extraction sorbent for preconcentration of copper (II). Mikrochim. Acta 2014, 182, 257-264. [CrossRef]

38. Xu, J.; Sun, Y.; Zhang, J. Solvothermal synthesis of $\mathrm{Fe}_{3} \mathrm{O}_{4}$ nanospheres for high-performance electrochemical non-enzymatic glucose sensor. Sci. Rep. 2020, 10, 16026. [CrossRef] [PubMed]

39. Zhu, M.; Diao, G. Synthesis of porous $\mathrm{Fe}_{3} \mathrm{O}_{4}$ nanospheres and its application for the catalytic degradation of xylenol orange. J. Phys. Chem. C 2011, 115, 18923-18934. [CrossRef]

40. Chang, R.; Goldsby, K.A. Chemistry, 11th ed.; McGraw-Hill Education: New York, NY, USA, 2012.

41. Eastman, E.D.; Rollefson, G.K. Physical Chemistry, 1st ed.; McGraw-Hill: New York, NY, USA, $1974 ;$ p. 307.

42. Borecki, M.; Korwin-Pawlowski, M.L.; Beblowska, M.; Szmidt, J.; Jakubowski, A. Optoelectronic Capillary Sensors in Microfluidic and Point-of-Care Instrumentation. Sensors 2010, 10, 3771-3797. [CrossRef]

43. Wei, X.; Liu, T.; Li, J.; Chen, X. A magnetic-controlled amperometric biosensor based on composite bio-particulates $\mathrm{Fe}_{3} \mathrm{O}_{4}$ and nano-au with the signal enhancement by increasing loading of horseradish peroxidase. Int. J. Electrochem. Sci. 2001, 6, 4953-4966.

44. $\mathrm{Li}, \mathrm{J}$;; Gao, H. A renewable potentiometric immunosensor based on $\mathrm{Fe}_{3} \mathrm{O}_{4}$ nanoparticles immobilized Anti-IgG. Electroanalysis 2008, 20, 881-887. [CrossRef]

45. Na, C.J.; Yoo, M.J.; Tsang, D.C.W.; Kim, H.W.; Kim, K.H. High-performance materials for effective sorptive removal of formaldehyde in air. J. Hazard. Mater. 2019, 366, 452-465. [CrossRef] [PubMed]

46. Shahzad, A.; Jang, J.; Lim, S.R.; Lee, D.S. Unique selectivity and rapid uptake of molybdenum-disulfidefunctionalized MXene nanocomposite for mercury adsorption. Environ. Res. 2020, 182, 109005. [CrossRef] [PubMed]

47. Pham, X.N.; Nguyen, T.P.; Pham, T.N.; Tran, T.T.N.; Tran, T.V.T. Synthesis and characterization of chitosan coated magnetite nanoparticles and their application in curcumin drug delivery. Adv. Nat. Sci. Nanosci. Nanotechnol. 2016, 7, 045010. [CrossRef] 
48. Li, C.; Wei, Y.; Liivat, A.; Zhu, Y.; Zhu, J. Microwave-solvothermal synthesis of $\mathrm{Fe}_{3} \mathrm{O}_{4}$ magnetic nanoparticles. Mater. Lett. 2013, 107, 23-26. [CrossRef]

49. Ren, W.; Ai, Z.; Jia, F.; Zhang, L.; Fan, X.; Zou, Z. Low temperature preparation and visible light photocatalytic activity of mesoporous carbon-doped crystalline $\mathrm{TiO}_{2}$. Appl. Catal. B Environ. 2007, 69, 138-144. [CrossRef]

50. Fan, H.-L.; Li, L.; Zhou, S.-F.; Liu, Y.-Z. Continuous preparation of Fe3O4 nanoparticles combined with surface modification by L-cysteine and their application in heavy metal adsorption. Ceram. Int. 2016, 42, 4228-4237. [CrossRef]

51. Chen, T.; Zhang, X.; Qian, J.; Li, S.; Jia, X.; Song, H.J. One-step hydrothermal synthesis of carbon@ $\mathrm{Fe}_{3} \mathrm{O}_{4}$ nanoparticles with high adsorption capacity. J. Mater. Sci. Mater. Electron. 2014, 25, 1381-1387. [CrossRef]

52. Tran, L.; Wu, P.; Zhu, Y.; Liu, S.; Zhu, N. Comparative study of Hg(II) adsorption by thiol- and hydroxylcontaining bifunctional montmorillonite and vermiculite. Appl. Surf. Sci. 2015, 356, 91-101. [CrossRef]

53. Tran, L.; Wu, P.; Zhu, Y.; Yang, L.; Zhu, N. Highly enhanced adsorption for the removal of Hg(II) from aqueous solution by Mercaptoethylamine/Mercaptopropyltrimethoxysilane functionalized vermiculites. J. Colloid Interface Sci. 2015, 445, 348-356. [CrossRef]

54. Li, B.; Zhang, Y.; Ma, D.; Shi, Z.; Ma, S. Mercury nano-trap for effective and efficient removal of mercury(II) from aqueous solution. Nat. Commun. 2014, 5, 5537. [CrossRef]

55. Husnain, S.M.; Kim, J.-H.; Lee, C.S.; Chang, Y.-Y.; Um, W.; Chang, Y.-S. Superparamagnetic nalidixic acid grafted magnetite $\left(\mathrm{Fe}_{3} \mathrm{O}_{4} / \mathrm{NA}\right)$ for rapid and efficient mercury removal from water. RSC Adv. 2016, 6, 35825-35832. [CrossRef]

56. Rinzin, U.; Singjai, P.; Wilairat, P.; Meejoo, S. Mechanochemical treated multi-walled carbon nanotubes for incorporation of metal ions. Adv. Mater. Res. 2008, 55, 537-540. [CrossRef]

57. Pan, S.; Shen, H.; Xu, Q.; Luo, J.; Hu, M. Surface mercapto engineered magnetic $\mathrm{Fe}_{3} \mathrm{O}_{4}$ nanoadsorbent for the removal of mercury from aqueous solutions. J. Colloid Interface Sci. 2012, 365, 204-212. [CrossRef] [PubMed]

58. Kamari, A.; Yusoff, S.N.M.; Abdullah, F.; Putra, W.P. Biosorptive removal of Cu(II), Ni(II) and Pb(II) ions from aqueous solutions using coconut dregs residue: Adsorption and characterisation studies. J. Environ. Chem. Eng. 2014, 2, 1912-1919. [CrossRef]

59. Tsai, W.-C.; de Luna, M.D.G.; Bermillo-Arriesgado, H.L.P.; Futalan, C.M.; Colades, J.I.; Wan, M.-W. Competitive fixed-bed adsorption of $\mathrm{Pb}(\mathrm{II}), \mathrm{Cu}(\mathrm{II})$, and $\mathrm{Ni}(\mathrm{II})$ from aqueous solution using chitosan-coated bentonite. Int. J. Polym. Sci. 2016, 2016, 1608939. [CrossRef]

60. Li, Q.; Wang, Z.; Fang, D.-M.; Qu, H.-Y.; Zhu, Y.; Zou, H.-J.; Chen, Y.-R.; Du, Y.-P.; Hu, H.-L. Preparation, characterization, and highly effective mercury adsorption of L-cysteine-functionalized mesoporous silica. New J. Chem. 2014, 38, 248-254. [CrossRef]

61. Jeon, C.; Ha Park, K. Adsorption and desorption characteristics of mercury(II) ions using aminated chitosan bead. Water Res. 2005, 39, 3938-3944. [CrossRef]

62. Kyzas, G.; Deliyanni, E. Mercury(II) Removal with modified magnetic chitosan adsorbents. Molecules 2013, 18, 6193-6214. [CrossRef]

63. Javadian, H.; Taghavi, M. Application of novel Polypyrrole/thiol-functionalized zeolite Beta/MCM-41 type mesoporous silica nanocomposite for adsorption of $\mathrm{Hg}^{2+}$ from aqueous solution and industrial wastewater: Kinetic, isotherm and thermodynamic studies. Appl. Surf. Sci. 2014, 289, 487-494. [CrossRef]

64. Alibaba Supplier. Available online: https://offer.alibaba.com (accessed on 18 November 2020).

Publisher's Note: MDPI stays neutral with regard to jurisdictional claims in published maps and institutional affiliations.

(C) 2020 by the authors. Licensee MDPI, Basel, Switzerland. This article is an open access article distributed under the terms and conditions of the Creative Commons Attribution (CC BY) license (http://creativecommons.org/licenses/by/4.0/). 